\title{
"We will abstain from eating any kind of food at the hotel": On Analyzing and Teaching Pragmatic and Other Aspects of English as a Global Language
}

\author{
Joachim Grzega (Pappenheim/Eichstätt-Ingolstadt)
}

\begin{abstract}
The article deals with aspects of analyzing and teaching English as a global language. Apart from a few remarks on phonetics, lexis and morphosyntax, its specific focus are pragmalinguistic issues. After a brief state-of-the-art, analyses of both natural and experimentally elicited language data from oral and written contexts are presented. The analyses rest on both qualitative approaches (VOICE and You Tube clips) and quantitative approaches (one type of DPTs, two types of MJTs and one type of semantic differential). The studies show that quantitative analyses with experimental methods often falsify hypotheses that have suggested themselves from prior qualitative research ("let-it pass principle" among natives and non-natives) and from normative language guides ("learner-book illusion", "complex-is-polite principle", "middle slots relevance"). The article then shows how the linguistic findings from such experimental designs can and should be rendered into principles and components for Teaching English as a Global Language, which would require constant work-in-progress models. Concrete examples are given from Basic Global English (BGE), which aims to prepare for global citizenship by incorporating transculturally effective strategies at the elementary level.
\end{abstract}

\section{$1 \quad$ Introduction}

Research on English as a lingua franca (ELF), or, more generally, English as a global language (EGL), has been gaining more and more attraction over the past years. Apart from EGL, we also find other synonyms, which I refrain from listing here, though. The terms are not used unanimously in the literature (cf., e.g., Mortensen 2013 on this issue). In some studies, for instance, ELF conversations are defined as including at least one non-native participant, in other studies they are defined as including only non-native participants. I use ELF in the former sense. I very consciously include native speakers in my use of ELF (as a function) and EGL (as a system). In my view, analysing and teaching English as a global language does not make sense if it excludes the native speakers of the globe. Whatever the precise definition in the literature, they always somehow include the use of English by nonnative speakers. A number of valuable analyses has been published on this issue. Important corpora have been and are still being collected. Three observations and desiderata can be formulated on ELF/EGL research: 
- While there is a vast amount of journal articles, conference proceedings and monographs on pragmalinguistic details, there are fewer generic or overall publications for pragmalinguistic aspects than for phonetic, morphological, syntactic and lexical features. This is understandable for at least three reasons: (1) Pragmalinguistics offers a relatively huge amount of details to be considered; (2) tremendous resources of time and linguistic data are needed to find comparable contexts; (3) deep structures, or functional-cognitive aspects or illocutionary forces, are invisible and leave more space for interpretation.

- The fascination of naturally produced ELF data has led to a neglect of the value of experimentally achieved comparable data.

- All ELF/EGL researchers see relevance in their studies for teaching English. However, apart from some vague ideas, teaching English as a global language continues to be largely untilled soil.

There is no room in this article to summarize all results that pragmatic and other linguistic studies on ELF have offered. This article predominantly aims at showing that in order to teach the pragmatics of English as a global language a variety of methods is fruitful. The single sections could also have been published as separate articles. However, putting the sections together is necessary to show two things: (1) Different analyzing techniques should not be seen as rivalling schools, but as supplementary, cooperative approaches. (2) Pragmalinguistic analyses do not have to end with stating empirical results, but can easily be transferred into educational components if there is an adequately flexible teaching concept. The article will therefore firstly put focus on how pragmalinguistic aspects-here: conversational strategies within certain given scripts and word-connotations (as a topic at the edge of pragmatics and semantics) — can be analyzed by combining both qualitative and quantitative analyses of both naturally and artificially produced data. Secondly, it will offer a concept for concrete implementations of ELF/EGL research results in teaching EGL.

\section{$2 \quad$ Analyzing English as a Global Language}

\subsection{Ethnographic Methods and Some Results}

Basic ethnographic methods that can be used in ELF/EGL research already go back to Hall (1959, 1963, 1976) and Hymes (1964, 1972a, 1972b). One way to analyze the use of English by non-natives in lingua-franca situations is noting down particularities in natural conversations, either immediately when a noteworthy form is overheard or while analyzing a prior recording. The latter technique was employed by Jennifer Jenkins, who was the first to give ELF a more in-depth treatment. Analyses are also possible thanks to the corpora that exist today, the following of which are among the larger ones (not all of them are generally accessible, though):

- VOICE (= Vienna-Oxford International Corpus of English; cf. the bibliography at http://voice.univie.ac.at, accessed April 15, 2011). 
- ELFA (= Corpus of English as a Lingua Franca in Academic Settings, cf. the bibliography at http://www.helsinki.fi/englanti/elfa/index.html, accessed May 12, 2015)

- $\quad \operatorname{AAC~(=~Alpine~Adriatic~Corpus,~cf.,~e.g.,~James~2000)~}$

- ICE (= International Corpus of English, cf. the bibliography at http://icecorpora.net/ice/, accessed May 12, 2015)

- LINDSEI (= Louvain International Database of Spoken English Interlanguage; cf. the bibliography at http://www.uclouvain.be/en-cecl-lindsei.html, accessed May 12, 2015)

- $\quad$ L2C by Prodromou (2008)

- the corpus of Euro-English by Mollin (2006)

- the Hamburg ELF corpus (e.g. House 2010)

- the corpus by Cogo and Dewey (2012)

- the ASEAN Corpus by Kirkpatrick (serving as a basis for the ACE (= Asian Corpus of English) (cf., e.g., Kirkpatrick 2010)

These corpora can also be used to address pragmalinguistic questions - to a larger extent than they have been used for that so far. Corpus analyses have let to the definition of a set of linguistic features that should be respected in intercultural conversations in order to avoid unintelligibility (e.g. Jenkins 2003, Seidlhofer 2007 and the state-of-the-art article by Jenkins/Cogo/Dewey 2011). This "lingua franca core" includes phonological, morphological and syntactic features. Some morphosyntactic observations, though, have pragmalinguistic implications, for instance the structure of interrogatives. Interrogatives should be clearly marked, either by using the standard English word-order or by choosing the word-order of declaratives with a raising intonation at the end (own observations, but see also, e.g., Björkmann 2008). However, it could be underlined, in a concept for teaching ELF/EGL, that the second option, the intonation question, produces sentences with a larger interpretability of the underlying illocutionary force when it does not include an interrogative pronoun or determiner. Depending on the context, such an interrogative may be interpreted as an expressive ('I can't believe it.'), maybe included with a directive ('Is this really so?') or it may be interpreted as a true information question. This can be demonstrated by the following passage from VOICE (line V.LEcon8.144-148).

1 Person 1: You can use your school ID?

2 Person 2: No, it's not the school ID, but this international ID card.

3 Person 1: Yeah, but I, I have, I have the ISIC also. But you can use your school ID?

In addition, I collected English interviews from lingua-franca constellations that were available on YouTube in December 2010. This shall be referred to as YELF (YouTube English as a Lingua Franca Corpus). The corpus consists of 19 clips, showing 19 interviewers and 23 interviewees, amounting to 86 minutes. The interviews are from the worlds of sports, entertainment, business and politics. They show 19 different types of intercultural constellations. As can be expected, there are many unproblematic deviations from native standard grammar and pragmatic features that may not be considered natural by native 
speakers. An analysis of YELF (in which I was partly supported by my student Tobias Radl) yields that there is no evident breakdown that could be attributed to phonetic aspects. But there is one interesting breakdown in a conversation between the Brazilian sportsman Cristiano Ronaldo and a Croatian interviewer, in which Ronaldo does not understand the interviewer's question: Do you sometimes do you wish for more freedom?. This could either be due to the grammatical deviation from standard English or due to the too low volume of the second (and unusual) do you. Pragmatically interesting is the strategy to get out of this situation. (http://www.youtube.com/watch?v=ELkk0-qOFn8, time 1:21, accessed April 15, 2015):

(2) 01 Interviewer: Do you sometimes do you wish for more freedom. (voice going down)

02 Ronaldo: (putting his head slightly more into the interviewer's direction) Say again!

03 Ronaldo: (smiling) Sorry! (NOT Sorry?)

04 Interviewer: Hgh (embarrassed laugh). You're deaf.

05 Both: $\quad$ laughing (4 sec.).

06 Ronaldo: More freedom?

07 Interviewer: Yes.

08 Interviewer: So that you can go free around with some girls to walk free

09 Interviewer: that nobody follows you.

10 Interviewer: Do you wish for that.

11 Ronaldo: Well ... at that moment it is quite difficult.

Ronaldo, for whatever reason, does not understand, asks the interviewer to repeat the question and apologizes. Despite the apology, the interviewer feels embarrassed and tries to put the blame - even if humorously - on Ronaldo. Both laugh and then Ronaldo finds a solution by repeating the last phrase of the question, thus enhancing a reformulation, or explanation, on the interviewer's side (who may have a different concept of freedom or, possibly, free-time).

In another YELF clip, a Russian woman interviews an Arab female fashion designer. In order to avoid face-threatening situations she uses a pre-empting strategy, namely remarks on a meta-level, raising the awareness of cultural differences, before the actual question. Here is the first instance (http://www.youtube.com/watch?v=7pvw8VW3mwY, time 0'26, accessed April 15, 2015, lines with the same number indicate that the utterances occurred simultaneously, capitalization symbolises emphasized pronunciation, a colon indicates lengthening):

(3) 01 Interviewer:

02 Interviewee:

02 Interviewer:

03 Interviewer:

04 Interviewee:

04 Interviewer:

05 Interviewee:

06 Interviewee:

06 Interviewer:

07 Interviewer:
I will ask you a VE:RY stupid question.

nods

And please don't get upset

because we're really,

Not at all (shaking head, smiling).

it's it's just a lack of knowledge.

Absolute- (laughing)

-ly. (laughing)

Tell me

if the females in Arabic Emerates 
08 Interviewee: $\quad$ Yup. (smiling, looking attentively)

09 Interviewer: $\quad$ are always wearing black veil

10 Interviewer: <unintelligible>,

10 Interviewee: nods

11 Interviewer: $\quad$ why do they need fashion for?

11 Interviewee: $\quad$ nods with a few laughs

12 Interviewee: laughs

12 Interviewer: $\quad$ Can you tell us exactly $<$ unintelligible $>$ ?

Then the interviewee gives her explanation in a fully friendly way, without no sign of negative feeling or stress. The second "cultural awareness raiser", or "meta-cultural remark", occurs at minute 3:39:

(4) 01 Interviewer:

And a couple of questions like for a woman,

02 Interviewer: yah?

02 Interviewee: nods

03 Interviewee: Yah.

04 Interviewer: Because we are so diffe-

05 Interviewer: -rent.

05 Interviewee: $\quad$ Yes yes. (with a big smile, almost a laugh)

Here, we have already entered the realm of pragmatics. As already said, comprehensive pragmatic results on lingua-franca communication in English are fewer then for other aspects. Mention may be made of Juliane House's contributions (e.g. 1999, 2009, 2010), the book by Cogo and Dewey (2012) as well as Meierkord's landmark study from 1996, which is an analysis of naturally occurring conversations among exchange students. Meierkord's study is still frequently quoted and includes the following major results.

- Interference from the native languages seems rare on the pragmatic level, in contrast to the phonetic, morphosyntactic and lexical level (the letters are illustrated, for instance, by James [1998] and the articles in Swan/Smith [2001]; others have provided opposite results on pragmalinguistic L1 interference [e.g. House 2010]).

- As long as a certain degree of understanding is achieved, interlocutors allow a relatively high degree of vagueness (Firth [1996] calls it the "let-it-pass principle", a principle that has also been confirmed for lingua-franca talk by House [1999, 2009, 2010]).

Apart from the corpora already cited, another source for pragmalinguistic analyses on English as a lingua franca is the English Wikipedia. It offers a tremendously large corpus of natural productions by native and non-native speakers alike on the pages that are not article pages, where standard English is obligatory. The dialogic interaction is not face-to-face and not immediate, so that it represents a genre of communication that has received considerably less attention in research than face-to-face communication.

Again, analyzing such naturally occurring written dialogs is possible, but it takes a lot of time to find comparable data and to find enough data to decide whether a certain communicative discomfort is due to, in Jenny Thomas's (1983) terminology, a sociopragmatic failure or a pragmalinguistic failure or still something else. Let us have a look at the following examples 
of inappropriate or unexpected addressing strategies and the reactions to them. In the following quotations, I have highlighted some passages in gray and added remarks in square brackets. The rest of the layout (underlining, coloring, boldprinting, crossing) has been kept from the original.

(5)

Mr. Meijssen GerardM took the time to post on my wall a while back regarding an FPC, which I "censored" to be safe for work and family. I wonder if he knows that POTD does skip over certain images. While Wikipedia isn't censored in general, the main page does not post (for lack of a better word) filth for the 7 million viewers per day to see. I invite him to explain why he expected the head of a penis to end up on the main page for a full day. I assume good faith that he knows exactly what he's talking about and is extremely familiar with FPC guidelines, but this example does lead to a question or two. wadester16 [from Germany] 00:00, 7 June 2009 (UTC)

$[\ldots]$

FYI I am GerardM, in my culture [= Netherlands] being only called by the surname is considered insulting. [....] Thanks, GerardM (talk) 06:56, 7 June 2009 (UTC)

If I (or Durova, for that matter) offended you by using your last name, my apologies; though the English Wikipedia is dominated by Westernraised users, where using your surname is considered more respectful. $[\ldots .$.

(6)

I know I may sound as if I'm saying that nearly everybody else has missed the point. This is because that is what I think. --Anticipation of a New Lover's Arrival, The [= Tony Sidaway, from the US] 03:26, 8 March 2008 (UTC)

TS, when you're convinced everyone else has missed the point, that usually means that you have.

Like many people I dislike having to guess who someone means by "SH" or "MM", and the use of initials instead of names is regarded as very rude in my culture [= ?]. --Anticipation of a New Lover's Arrival, The 03:13, 8 March 2008 (UTC)

(7)

No one indefinitely "banned" anyone, Mr. Thorne, and it certainly was far from "instant". This editor was indefinitely (indefinitely, not infinitely) blocked due to the egregiousness of the offense and the lack of understanding of why it was wrong. [....] Your defense of her is unnecessary and based on false assumptions. Please review the difference between a ban and a block. Tan | 39 02:20, 1 December 2009 (UTC)

In my culture [= Australia] using a persons's name as you have used "Mr Thorne" above, is seen as agressive and an insult, especially when you know the first name. I 
WP:AGF so I assume no ill intent. In future, though, please call me Nick. [....] Nick

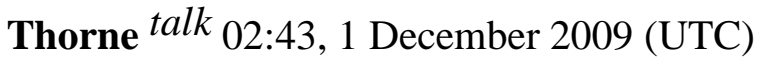

How can we interpret the communicative discomforts in these exchanges? Does the uncommon choice of address terms lead to offence? Or does the uncommon choice of address terms lead to offence in face-threatening acts only, such as corrections and other forms of criticisms? Or does the uncommon choice of address terms serve as the motivation for a counter-attack? This is hard to find out by collecting exclusively natural data. Pragmatic aspects are so much tied to invisible, cognitive aspects and they rely so much more on the extra-linguistic context-suffice it to quote some basic literature on speech-acts, communicative competence, conversational maxims and politeness theory here: Austin (1962), Searle (1969, 1976), Bateson (1972), Hymes (1964, 1972a, 1972b), Grice (1975), Brown/Levinson (e.g. 1987), Goffman (1955, 1967), Leech (1983). In pragmalinguistic studies, it seems particularly adequate to gather data by artifically eliciting text-production, but: on potentially naturally occurring situations.

\subsection{Discourse Creation Tasks and Metalinguistic Judgment Tasks and Some Results}

Frequent and widely accepted techniques for gathering data for speech-act analysis, which was first used in a cross-cultural project on request and apologies (Blum-Kulka/House/Kasper 1989) are

- the discourse completion test (DCT), where informants have to complete a dialog, for which a scenario, potentially a first brick of dialog and a rejoinder of the interlocutor are already given.

- the dialog construction questionnaire (DCQ), which is like a DCT, but without a rejoinder

- the dialog production task (DPT), where not a single part of dialog is offered, but where an entire text has to be created for a given scenario.

I have already commented on these techniques elsewhere (Grzega/Schöner 2008, Grzega 2013: 29-32). Suffice it to say here that all three techniques only elicit the first or most typical answer that comes to an informant's mind, but not the whole spectrum of answers that an informant may possibly resort to. This could result in wrong deductions about culturespecificity. DCTs allow only for a tentative classification of strategies that will occur in natural speech and a picture of stereotypical perceptions. These caveats led to the development of meta-linguistic judgement tests (MJT), or meta-pragmatic judgement tests, as already suggested by Olshtain/Blum-Kulka (1984) or in alternative ways by Chen (1996) and Hinkel (1997). An MJT typically unveils the most frequent types of utterances gathered in a prior DCT or DCQ and asks informants to rank the appropriateness of the utterances. A certain weakness of this test is indeed that informants can evaluate merely a restricted amount of linguistic forms. Also of note, a number of studies has shown that informants' introspections of their frequent or typical sometimes misrepresent their actual use of words (cf., e.g., Labov 1966, Blom/Gumperz 1972, Grzega 1997: 166). Demonstrably, this even applies to trained linguists (cf. Brouwer/Gerritsen/deHaan 1979: 47). This appears to hold predominantly true when informants have to create spoken language in a written medium, 
resulting, inter alia, in unnatural reductions of repetition, negotiation, hedging, elaboration, utterance length, and variation (cf. Beebe 1985: 3 and 11). So, MJTs, too, enable but provisional classifications and a sense for stereotypical perceptions of language use. Of course, it is not denied that these are already valuable achievements.

In my own project, the first step was to have international students participate in a DPT on a non-face-threatening act, namely an e-mail asking for a reservation of a hotel room, which can be considered a situation that a lot of people put themselves into today. It is, again, a nonface-to-face non-synchronous dialog situation. The instruction read this:

You want to spend your Christmas vacation in [X-city] together with a friend. You have chosen an inexpensive hotel that also offers rooms without breakfast. Write to the e-mail indicated above and make a reservation for such a double room at this hotel.

All informants were given the text in their mother tongues in order to avoid prompting any standard English words or phrases. For the further steps of the project I only took into account countries for which I had at least 7 informants: Germany (28), Italy (13), France (9), Spain (9), the US (9). The US informants were particularly interesting to compare native and nonnative use. The question was: will these e-mails be communicatively successful? Do they meet readers' expectations of politeness? Of course, the question may be raised: Why should politeness be relevant in such a genre? Based on informal interviews, I assume that hotels, too, are more willing to cooperate with customers whom they do not perceive as "difficult".

For this, some sort of assessment test was required. I decided to create a metapragmatic judgement task (MJT) for a non-face-to-face non-synchronous situation.

You are temporarily working for a hotel in your home region. On its website the hotel offers different types of rooms and even gives the choice between stays with breakfast and stays without breakfast. Your specific job at the hotel is to answer all kinds of e-mails from all over the world. Most of the e-mails are reservations. Sometimes e-mails appear rather polite, sometimes overpolite, sometimes impolite. In the following questionnaire, your first task is to evaluate different phrases for the single parts of such e-mails (salutation, preliminary remark, actual reservation, closing formula). In the second part, you will be asked about how you view specific sentences from actual e-mails. Please answer rather quickly as we want to get your first impression.

Since the texts to be analyzed consisted of various elements where politeness could be violated, I decided to split the script "e-mailed hotel reservation" into 7 slots (based on the emails I had received).

Then I collected each country's most prominent type(s) of form for each slot as well as some forms that do not occur among the US informants at all. As in a classical MJT, I asked informants - who were different from those that participated in the DPT - to classify each form as "very appropriate", "rather appropriate", "rather inappropriate" or "very inappropriate". But to make sure that the MJT informants associate appropriateness with politeness and not with spelling or grammar, spelling and grammar errors were levelled out (In contrast, the second part of this MJT - see below-complete or large parts of e-mails presented exactly the way they were handed, i.e. with spelling, grammar and vocabulary errors). 
As of yet, the MJT was completed by

- 75 native speakers, the largest groups formed by informants from the US (45) and the UK (18), and

- 243 non-native speakers, the largest groups formed by informants from Germany (83), Poland (81), France (17), Finland (12), Hungary (9), Italy (8), and Russia (7).

We will first take a look at the salutation and valediction formulae. The tables show the figures for the British informants, the American informants, the group of informants that are non-native speakers of English, and in particular the figures for the nations just mentioned. The figures are not the arithmetic means, but the median of the answers on the scale "very appropriate" (1), "rather appropriate" (2), "rather inappropriate" (3), "very inappropriate" (4). The median is the numerical value separating the higher half of informant answers from the lower half of informant answers.

\section{(1) Salutation}

\begin{tabular}{|l|l|c|c|c|c|c|c|c|c|c|c|}
\hline Formulation & & US & UK & NNS & DE & FR & IT & FI & PL & HU & RU \\
\hline $\begin{array}{l}\text { a. Dear Sir or } \\
\text { Madam }\end{array}$ & DE & 1 & 1 & 1 & 1 & 1 & 2 & 1 & 1 & 1 & 1 \\
\hline $\begin{array}{l}\text { b. Dear } \\
\text { Sir/Madam }\end{array}$ & IT & 2 & 1 & 2 & 2 & 2 & 1 & 1 & 1 & 1 & 2 \\
\hline $\begin{array}{l}\text { c. Dear ladies } \\
\text { and gentlemen }\end{array}$ & *US & 3 & 3 & 2 & 2 & 3 & 3 & 2 & 2 & 3 & 1 \\
\hline d. Hello & US, ES & 2 & 2 & 3 & 3 & 2 & 3 & 2 & 3 & 2 & 2 \\
\hline e. Good morning & FR & 2 & 2 & 2 & 3 & 2 & 2 & 2 & 2 & 3 & 2 \\
\hline f. --- & ES & 3 & 3 & 4 & 4 & 4 & 4 & 3 & 4 & 4 & 3 \\
\hline
\end{tabular}

\section{(6) Closing formula}

\begin{tabular}{|l|l|c|c|c|c|c|c|c|c|c|c|}
\hline Formulation & & US & UK & NNS & DE & FR & IT & FI & PL & HU & RU \\
\hline $\begin{array}{l}\text { a. Yours } \\
\text { faithfully, }\end{array}$ & *US & 3 & 1 & 1 & 2 & 2 & 3 & 2 & 1 & 1 & 1 \\
\hline $\begin{array}{l}\text { b. Sincerely } \\
\text { yours, }\end{array}$ & DE & 2 & 2 & 2 & 2 & 2 & 2 & 1 & 2 & 1 & 1 \\
\hline c. Best regards, & IT & 1 & 1 & 2 & 2 & 2 & 2 & 1 & 2 & 2 & 1 \\
\hline d. Kind regards, & IT & 1 & 1 & 2 & 2 & 2 & 1 & 1 & 2 & 2 & 2 \\
\hline $\begin{array}{l}\text { e. } \text { Thank you. } \\
\text { Kind regards, }\end{array}$ & IT & 1 & 1 & 2 & 1 & 2 & 1 & 1 & 2 & 2 & 2 \\
\hline $\begin{array}{l}\text { f. } \text { Thank you. } \\
\text { Sincerely yours, }\end{array}$ & DE & 1 & 2 & 2 & 2 & 2 & 3 & 1 & 2 & 1 & 2 \\
\hline g. Thank you. & US & 1 & 1 & 2 & 2 & 2 & 2 & 2 & 2 & 2 & 3 \\
\hline h. --- & FR, US & 3 & 4 & 4 & 4 & 4 & 4 & 3 & 4 & 4 & 3 \\
\hline
\end{tabular}


What can we observe? In many learner dictionaries (e.g. CIDE, DCE, OALD) we find that Dear Sir or Madam should be used as an opening formula in formal letters (the OALD also mentions To whom it may concern for American English, but this was not used by any of the American informants in this text-type). The interesting results for this first slot are the following.

- Indeed, all groups consider Dear Sir or Madam and Dear Sir/Madam appropriate variants.

- Hello, which is labeled informal by the dictionaries, is considered appropriate by both the average British and the average American informant. However, the average nonnative speaker (except the average informant from Finland, France and Russia) considers Hello inappropriate. It cannot be answered whether this is due to textbook descriptions from which non-native speakers learn. This could then be termed the "learner-book nimbus". (Good morning, too, is considered appropriate by both native and non-native informant groups, except for the Germans.)

- The un-English letter salutation Dear ladies and gentlemen is considered appropriate by the average non-native speaker, except the average French and Italian informants, while the native speakers consider this phrase inappropriate. (The native Englishspeaking informants' judgements are best mirrored by the French informants, then by the Finnish and Italian informants. The Germans most clearly deviate from the native speakers' judgements. The non-native speaker judgements' is best reflected by the Polish informants.)

All in all, the mass of non-native speakers seems to be trapped in a certain "complex-is-polite principle". Let us now have a look at the closing formulae. In many dictionaries (CIDE 815, DCE 978f., OALD R53) we find strict distinctions between different forms of valediction. The rule given is: When you don't know the addressee's name, you close the letter with Yours faithfully in Britain and Yours truly or Sincerely (yours) in the US; in Britain, Yours sincerely is used only when you know the addressee's name. In the textbook New Highlight 4, Unit 5, only Yours faithfully is given. The reality in my project is this:

- Yours truly was not used by any single American or non-native informant in the DPT. The most common valediction was a simple Thank you or "zero".

- All informants consider a lack of valediction the most inappropriate choice.

- British consider Yours faithfully indeed very appropriate, while Americans don't.

- Aside from this, the degree of perceived appropriateness varies. Except for the British Yours faithfully and the lack of a formula, Americans regard all of the forms as very or rather appropriate. As a matter of fact, it is quite surprising that Thank you and Thank you. Kind regards are considered appropriate as textbook models. Sincerely yours, labeled "American" by the textbooks, is seen as appropriate by American, British and non-native informants alike.

This leads us to the conclusion that native speakers perceive hotel reservation e-mails rather as relatives of informal letters than as relatives of formal letters. In sum, the actual use and 
acceptance of forms is not as strict as textbooks and dictionaries make us believe ("learnerbook illusion").

Let us now look at, and comment on, the other slots.

(2) Preliminary remark

\begin{tabular}{|c|c|c|c|c|c|c|c|c|c|c|c|}
\hline Formulation & & US & UK & NNS & $\mathrm{DE}$ & FR & IT & FI & $\mathrm{PL}$ & $\mathrm{HU}$ & $\mathrm{RU}$ \\
\hline $\begin{array}{l}\text { a. I am writing } \\
\text { you in order to } \\
\text { make a } \\
\text { reservation. }\end{array}$ & *US & 1 & 1 & 1 & 1 & 2 & 2 & 1 & 1 & 1 & 2 \\
\hline $\begin{array}{l}\text { b. My name is } \\
\text { Mikael Agricola. } \\
(=\text { introduction of } \\
\text { name })\end{array}$ & $\begin{array}{l}\text { IT, } \\
\text { (DE, } \\
\text { ES), } \\
\text { *US }\end{array}$ & 2 & 2 & 2 & 3 & 2 & 2 & 2 & 2 & 3 & 2 \\
\hline c. --- & all & 3 & 4 & 4 & 4 & 3 & 4 & 3 & 4 & 4 & 3 \\
\hline
\end{tabular}

On the quoted pages, the dictionaries also suggest using a phrase that could be seen as an illocutionary-force indicating device (IFID), i.e. an expression that explicitly says what the illocutionary force is. The term was coined by Searle (1969). None of the American informants actually used it in their mail ("learner-book illusion"), but the Americans as well as all other country informants consider such a phrase appropriate. Some non-native speakers introduced their name, which is considered inappropriate only by the German group.

(3) Booking request

\begin{tabular}{|l|l|c|c|c|c|c|c|c|c|c|c|}
\hline Formulation & & US & UK & NNS & DE & FR & IT & FI & PL & HU & RU \\
\hline $\begin{array}{l}\text { a. I would like to } \\
\text { book a double } \\
\text { room without } \\
\text { breakfast... } \\
\text { neutral style) }\end{array}$ & $\begin{array}{l}\text { DE, ES, } \\
\text { IT, FR }\end{array}$ & 1 & 1 & 1 & 2 & 1 & 1 & 2 & 1 & 2 & 2 \\
\hline $\begin{array}{l}\text { b. I would like to } \\
\text { reserve a double } \\
\text { room without } \\
\text { breakfast ... (= } \\
\text { educated style) }\end{array}$ & US & 1 & 1 & 2 & 1 & 2 & 1 & 1 & 2 & 1 & 2 \\
\hline $\begin{array}{l}\text { c. I would like to } \\
\text { make a } \\
\text { reservation for a } \\
\begin{array}{l}\text { double room } \\
\text { without breakfast } \\
\text {. (= legalese-like } \\
\text { style })\end{array}\end{array}$ & DE & 1 & 1 & 1 & 1 & 1 & 1 & 1 & 1 & 1 & 1 \\
\hline
\end{tabular}




\begin{tabular}{|l|l|c|c|c|c|c|c|c|c|c|c|}
\hline Formulation & & US & UK & NNS & DE & FR & IT & FI & PL & HU & RU \\
\hline $\begin{array}{l}\text { d. Is it possible to } \\
\text { book a double } \\
\text { room without } \\
\text { breakfast... (= } \\
\text { interrogatory). }\end{array}$ & (ES) & 1 & 1 & 2 & 2 & 2 & 1 & 1 & 2 & 2 & 2 \\
\hline
\end{tabular}

In this selection of phrases, I wanted to connect style and sentence type with politeness. There were no noteworthy country differences. All four variants were considered rather or even very appropriate.

\section{(4) Date}

\begin{tabular}{|l|l|c|c|c|c|c|c|c|c|c|c|}
\hline Formulation & & US & UK & NNS & DE & FR & IT & FI & PL & HU & RU \\
\hline $\begin{array}{l}\text { a.... from } \\
\begin{array}{l}\text { 07.08.09 to } \\
\text { 09.08.09 }\end{array}\end{array}$ & *US & 2 & 2 & 2 & 2 & 1 & 2 & 1 & 2 & 2 & 1 \\
\hline $\begin{array}{l}\text { b. ... from } \\
\begin{array}{l}\text { 08/07/09 to } \\
\text { 08/09/09 }\end{array}\end{array}$ & all & 2 & 2 & 2 & 2 & 2 & 1 & 2 & 2 & 2 & 2 \\
\hline $\begin{array}{l}\text { c.... from August } \\
\text { to August } 9\end{array}$ & all & 1 & 1 & 2 & 2 & 1 & 2 & 1 & 2 & 1 & 2 \\
\hline
\end{tabular}

Here, an international style-book such as Weiss (2005) advises the international sender to write out the month to avoid any misunderstandings triggered by the culturally varying order of day and month. Both native speaker groups consider the use of the month's name most appropriate, but the other patterns are also not inappropriate. The non-native groups, consider all patterns appropriate, but on deeper levels the picture of the non-native speakers is very mixed.

\section{(5) Booking confirmation}

\begin{tabular}{|c|c|c|c|c|c|c|c|c|c|c|c|}
\hline Formulation & & US & UK & NNS & $\mathrm{DE}$ & FR & IT & FI & PL & $\mathrm{HU}$ & RU \\
\hline $\begin{array}{l}\text { a. Please confirm } \\
\text { my booking _. }\end{array}$ & FR & 2 & 2 & 2 & 2 & 3 & 2 & 2 & 2 & 2 & 2 \\
\hline $\begin{array}{l}\text { b. } \underline{\text { Please confirm }} \\
\text { my booking as } \\
\text { soon as possible. }\end{array}$ & $\mathrm{DE}$ & 2 & 2 & 2 & 2 & 2 & 2 & 2 & 2 & 2 & 2 \\
\hline $\begin{array}{l}\text { c. } \text { I would be } \\
\text { grateful if you } \\
\text { would confirm my } \\
\text { booking as soon } \\
\text { as possible. }\end{array}$ & $\begin{array}{l}\text { DE, IT, } \\
\text { *US }\end{array}$ & 1 & 1 & 1 & 1 & 1 & 1 & 1 & 1 & 1 & 1 \\
\hline
\end{tabular}


Global Language

\begin{tabular}{|l|l|c|c|c|c|c|c|c|c|c|c|}
\hline Formulation & & US & UK & NNS & DE & FR & IT & FI & PL & HU & RU \\
\hline d. --- & IT, US & 3 & 4 & 4 & 4 & 4 & 4 & 3 & 4 & 4 & 3 \\
\hline
\end{tabular}

(The answers of ES were very mixed so that there is no strategy that is used by at least half of the Spanish informants.)

On the average, all groups agree that the use of the would construction is very appropriatealthough none of the native DPT informants used it - , but that the more direct constructions are still appropriate (except the French informants who evaluate the first entry as inappropriate).

The second part of the project consisted of randomly selected twelve DCTs which were quoted in part or in full exactly the way they were written. This time the classical MJT label appropriate was avoided to exclude that informants' view is predominantly on grammatical elements. Instead, the label polite was used; however, it should be realized that polite is not the end-pole of a "polite-impolite" scale. Rather, it seems the ideally balanced point on an "impolite - overpolite" scale. Overpoliteness was included because it may give the impression of insincerity and thus be as irritating as impoliteness. The MJT informants were then to decide whether each message presented to them was "unclear, "clear, but impolite", "clear and polite", "clear, but overpolite". Of course, the answer "clear" only shows that for the reader there was a clear message. Whether it is the one that the writer intended was not checked. From the results of the older studies summarized above and the first part of this study, the following hypotheses can be tested:

(1) MPJT informants coming from the same country as the DPT informants will categorize an e-mail as "unclear" not more frequently than those coming from other countries. (This is based on the observation that interferences which occur on the phonetic, morphosyntactic and lexical levels are more easily decodable by speakers of the same mother-tongue.)

(2) MPJT informants coming from the same country as the DPT informants will categorize an e-mail as "polite" as much as all countries taken together. (This is based on Meierkord's observation that on the pragmatic level interferences from the native culture are rare.)

(3) Non-native MPJT informants categorize an e-mail more often as "polite" than native informants (This is based on the observed "let-it-pass principle" by non-native speakers).

(4) As can be inferred from the first part of the questionnaire, the choice of the salutation and the valediction will not play a central role.

The figures in the following table are percentages. The names in the original messages have been altered; everything else was kept. If more than a quarter of a country's informants thinks that the e-mail is unclear or impolite, the figure is set in boldface. If more than half of a country's informants categorize an e-mail the same way, the figure is set in boldface and italics. 


\begin{tabular}{|l|c|c|c|c|}
\hline DE-1 & \multicolumn{3}{|c|}{$\begin{array}{l}\text { Dear sir/madam, I would like to book a double room from } 15 / 08 \text { to } \\
\text { inform you that we will abstain from eating any kind of food at the hotel. }\end{array}$} \\
\hline unclear & clear, but impolite & clear and polite & clear, but overpolite \\
\hline US & 6 & $\mathbf{5 6}$ & 28 & 11 \\
\hline NNS & 11 & 40 & 24 & 24 \\
\hline DE & 3 & 49 & 30 & 19 \\
FR & 2 & $\mathbf{6 0}$ & 17 & 21 \\
\hline IT & 6 & $\mathbf{5 3}$ & 29 & 12 \\
\hline FI & 0 & 29 & 29 & 43 \\
\hline PL & 0 & $\mathbf{7 5}$ & 17 & 8 \\
\hline HU & 3 & 29 & 49 & 0 \\
\hline RU & 0 & 4 & $\mathbf{6 7}$ & 14 \\
\hline all & 0 & $\mathbf{5 7}$ & 29 & 19 \\
\hline
\end{tabular}

DE-2 Hello, I'm interested to book a double room for 5 days stating the night form 20 to 21 December. My dates: Name: Olaf Jansson, Address: ....

\begin{tabular}{|l|c|c|c|c|}
\hline & unclear & clear, but impolite & clear and polite & clear, but overpolite \\
\hline UK & $\mathbf{2 9}$ & 0 & $\mathbf{7 1}$ & 0 \\
\hline US & $\mathbf{5 4}$ & 9 & 37 & 0 \\
NNS & 20 & 36 & 44 & 0 \\
\hline DE & 15 & 37 & 48 & 0 \\
FR & $\mathbf{3 1}$ & 44 & 19 & 6 \\
IT & $\mathbf{7 1}$ & 14 & 14 & 0 \\
\hline FI & $\mathbf{3 3}$ & 25 & 42 & 0 \\
PL & 16 & 42 & 42 & 0 \\
\hline HU & 0 & $\mathbf{6 1}$ & 33 & 0 \\
RU & 0 & 43 & $\mathbf{5 7}$ & 0 \\
all & $\mathbf{2 6}$ & 30 & 44 & 0 \\
\hline
\end{tabular}


Global Language

\begin{tabular}{|c|c|c|c|c|}
\hline \multirow[t]{2}{*}{ DE-3 } & \multicolumn{4}{|c|}{$\begin{array}{l}\text { Hello, I want to book a double bedroom over the period from August } 23 \text { to September } 72009 \\
\text { without breakfast. }\end{array}$} \\
\hline & unclear & clear, but impolite & clear and polite & clear, but overpolite \\
\hline UK & 6 & 12 & 82 & 0 \\
\hline US & 0 & 36 & 64 & 0 \\
\hline NNS & 5 & 55 & 38 & 2 \\
\hline $\mathrm{DE}$ & 3 & 65 & 31 & 1 \\
\hline FR & 6 & 65 & 30 & 0 \\
\hline IT & 14 & 57 & 29 & 0 \\
\hline FI & 8 & 50 & 42 & 0 \\
\hline PL & 8 & 47 & 41 & 4 \\
\hline HU & 0 & 78 & 22 & 0 \\
\hline RU & 0 & 43 & 57 & 0 \\
\hline all & 4 & 51 & 44 & 1 \\
\hline
\end{tabular}




\begin{tabular}{|c|c|c|c|c|}
\hline \multirow[t]{2}{*}{$\begin{array}{l}\text { DE- } \\
4\end{array}$} & \multicolumn{4}{|c|}{$\begin{array}{l}\text { Hello, I would like to book a double room for Mr. Jan Olafsson. Arriving at } 26 \text { Dezember, } \\
\text { leaving } 2 \text { January. I require a room excluding brakefast. Regards, Jan Olafsson. }\end{array}$} \\
\hline & unclear & clear, but impolite & clear and polite & clear, but overpolite \\
\hline UK & 0 & 18 & 82 & 0 \\
\hline US & 9 & 27 & 64 & 0 \\
\hline NNS & 4 & 36 & 56 & 4 \\
\hline $\mathrm{DE}$ & 2 & 37 & 58 & 2 \\
\hline FR & 6 & 35 & 59 & 0 \\
\hline IT & 0 & 57 & 43 & 0 \\
\hline FI & 0 & 17 & 83 & 0 \\
\hline PL & 10 & 38 & 44 & 7 \\
\hline HU & 0 & 44 & 44 & 11 \\
\hline RU & 0 & 43 & 57 & 0 \\
\hline all & 5 & 33 & 59 & 3 \\
\hline
\end{tabular}

FR- Hello, I want to spend my holidays in your city. My first question will concerne the fact that 1 I'm student and I want to know if you cann offer me some attractive price. ....

\begin{tabular}{|l|c|c|c|c|} 
& unclear & clear, but impolite & clear and polite & clear, but overpolite \\
\hline UK & $\mathbf{2 8}$ & 28 & 44 & 0 \\
US & 13 & 47 & 36 & 4 \\
NNS & 15 & $\mathbf{5 4}$ & 30 & 2 \\
\hline DE & 13 & $\mathbf{6 5}$ & 22 & 0 \\
FR & $\mathbf{2 9}$ & 47 & 24 & 0 \\
\hline IT & 0 & $\mathbf{7 1}$ & 29 & 0 \\
FI & 17 & 17 & 50 & 17 \\
PL & 19 & 35 & 30 & 17 \\
\hline HU & 22 & $\mathbf{6 7}$ & 11 & 0 \\
\hline RU & 14 & $\mathbf{8 6}$ & 0 & 0 \\
all & 16 & $\mathbf{5 2}$ & 30 & 2 \\
\hline
\end{tabular}


Global Language

FR- Hello, I would like to book a chamber for 2 persons without breakfasts. Do you have a

2 vacancy room from the 23 rd to the 26 of august? ....

\begin{tabular}{|l|c|c|c|c|} 
& unclear & clear, but impolite & clear and polite & clear, but overpolite \\
\hline UK & 6 & 11 & $\mathbf{7 8}$ & 6 \\
US & 4 & 13 & $\mathbf{7 6}$ & 7 \\
\hline NNS & 16 & 28 & $\mathbf{5 2}$ & 4 \\
DE & 16 & 27 & $\mathbf{5 6}$ & 2 \\
FR & $\mathbf{3 5}$ & 24 & 41 & 0 \\
\hline IT & $\mathbf{2 9}$ & 14 & $\mathbf{5 7}$ & 0 \\
FI & 0 & 8 & $\mathbf{9 2}$ & 0 \\
\hline PL & 17 & 38 & 38 & 8 \\
\hline HU & 22 & 33 & 44 & 0 \\
RU & 14 & 43 & 29 & 14 \\
all & 13 & 25 & $\mathbf{5 8}$ & 5 \\
\hline
\end{tabular}

FR- Hello. I would like to book a double room for Aug 7 to Aug 10. It would be great if you could 3 answer us within a fortnight. Regards, P. Moto.

\begin{tabular}{|l|c|c|c|c|} 
& unclear & clear, but impolite & clear and polite & clear, but overpolite \\
UK & 0 & 22 & $\mathbf{7 8}$ & 0 \\
\hline US & 11 & 30 & $\mathbf{5 5}$ & 5 \\
NNS & 5 & 29 & $\mathbf{6 2}$ & 4 \\
\hline DE & 6 & 32 & $\mathbf{6 1}$ & 2 \\
FR & 6 & 29 & $\mathbf{6 5}$ & 0 \\
IT & 0 & 29 & $\mathbf{5 7}$ & 14 \\
\hline FI & 8 & 0 & $\mathbf{9 2}$ & 0 \\
PL & 4 & 34 & $\mathbf{5 6}$ & 7 \\
\hline HU & 11 & $\mathbf{5 6}$ & 33 & 0 \\
RU & 14 & 14 & $\mathbf{7 1}$ & 0 \\
\hline all & 6 & 30 & $\mathbf{6 1}$ & 4 \\
\hline
\end{tabular}


FR- Dear madam/sir - Have you a room with double bed or two simple bed available for a week at 4 this date: 25-27 August? Regards, T. Kim

\begin{tabular}{|l|c|c|c|c|} 
& unclear & clear, but impolite & clear and polite & clear, but overpolite \\
\hline UK & $\mathbf{2 8}$ & 6 & $\mathbf{6 7}$ & 0 \\
US & $\mathbf{2 8}$ & 7 & $\mathbf{5 6}$ & 10 \\
\hline NNS & 20 & 30 & 48 & 3 \\
DE & 25 & 28 & 47 & 1 \\
FR & 24 & 12 & $\mathbf{6 5}$ & 0 \\
\hline IT & 14 & 0 & $\mathbf{7 1}$ & 14 \\
FI & 25 & 8 & $\mathbf{5 8}$ & 8 \\
\hline PL & 8 & 47 & 42 & 4 \\
\hline HU & $\mathbf{3 3}$ & 33 & 33 & 0 \\
RU & 17 & $\mathbf{6 7}$ & 17 & 4 \\
all & 21 & 24 & $\mathbf{5 1}$ & 4 \\
\hline
\end{tabular}

IT- Hello, I'm intentioned to spend my holidays in your city by a friend of mine.

1 Therefore, I want to reserve a room for us from August 10 to August 12. Thank you, R. Ibrahim

\begin{tabular}{|l|c|c|c|c|}
\hline & unclear & clear, but impolite & clear and polite & clear, but overpolite \\
\hline UK & $\mathbf{4 4}$ & 17 & 39 & 0 \\
\hline US & $\mathbf{4 4}$ & 9 & 38 & 9 \\
NNS & $\mathbf{3 2}$ & 22 & 33 & 14 \\
DE & $\mathbf{3 5}$ & 16 & 39 & 10 \\
\hline FR & $\mathbf{5 3}$ & 12 & 29 & 6 \\
IT & $\mathbf{2 9}$ & 29 & 14 & 29 \\
\hline FI & $\mathbf{4 2}$ & 17 & 42 & 0 \\
PL & 19 & 35 & 29 & 17 \\
HU & $\mathbf{3 3}$ & 22 & 33 & 11 \\
\hline RU & $\mathbf{2 9}$ & 0 & 43 & 29 \\
all & $\mathbf{3 4}$ & 19 & 36 & 11 \\
\hline
\end{tabular}


Global Language

\begin{tabular}{|c|c|c|c|c|}
\hline \multirow[t]{2}{*}{ IT-2 } & \multicolumn{4}{|c|}{$\begin{array}{l}\text { Dear madam/sir - I would like a room for the night from August } 7 \text { to August } 9 \text { inclusive. Kind } \\
\text { regards, K. Habib }\end{array}$} \\
\hline & unclear & clear, but impolite & clear and polite & clear, but overpolite \\
\hline UK & 22 & 11 & 67 & 0 \\
\hline US & 37 & 9 & 50 & 2 \\
\hline NNS & 26 & 24 & 49 & 2 \\
\hline $\mathrm{DE}$ & 35 & 29 & 36 & 0 \\
\hline FR & 24 & 24 & 53 & 0 \\
\hline IT & 14 & 29 & 57 & 0 \\
\hline FI & 42 & 8 & 50 & 0 \\
\hline $\mathrm{PL}$ & 18 & 24 & 55 & 4 \\
\hline $\mathrm{HU}$ & 22 & 22 & 56 & 0 \\
\hline RU & 29 & 29 & 43 & 0 \\
\hline all & 27 & 21 & 51 & 2 \\
\hline
\end{tabular}

US- I would like to reserve a room for two people from Aug 7 to Aug 10. We would like two beds 1 or at least one queen size bed if two beds are not available. We would like just the room and do not wish to utilize your hotel's breakfast option.

\begin{tabular}{|l|c|c|c|c|} 
& unclear & clear, but impolite & clear and polite & clear, but overpolite \\
\hline UK & 6 & 11 & $\mathbf{6 1}$ & 22 \\
US & 0 & 7 & $\mathbf{8 2}$ & 11 \\
\hline NNS & 5 & 33 & 48 & 15 \\
DE & 4 & 35 & 45 & 17 \\
\hline FR & 18 & 30 & 47 & 0 \\
IT & 0 & 71 & 29 & 0 \\
FI & 0 & 8 & $\mathbf{7 5}$ & 17 \\
\hline PL & 5 & 40 & 36 & 18 \\
HU & 0 & 33 & $\mathbf{5 6}$ & 11 \\
\hline RU & 0 & 43 & 43 & 14 \\
all & 4 & 28 & $\mathbf{5 4}$ & 15 \\
\hline
\end{tabular}




\begin{tabular}{|l|c|c|c|c|}
\hline $\begin{array}{l}\text { US- } \\
\mathbf{2}\end{array}$ & \multicolumn{4}{|l|}{$\begin{array}{l}\text { Hello - Do you have any vacancies for this coming weekend? I would like to book a double } \\
\text { room for two people - no breakfast required. Regards, T. Rajid }\end{array}$} \\
\hline unclear & clear, but impolite & clear and polite & clear, but overpolite \\
\hline US & 17 & 0 & $\mathbf{8 3}$ & 0 \\
\hline NNS & 16 & 7 & $\mathbf{8 4}$ & 0 \\
\hline DE & 13 & 25 & $\mathbf{5 8}$ & 1 \\
FR & 6 & 21 & $\mathbf{6 5}$ & 2 \\
\hline IT & 0 & 13 & $\mathbf{8 1}$ & 0 \\
FI & 25 & 0 & $\mathbf{1 0 0}$ & 0 \\
\hline PL & 20 & 8 & $\mathbf{6 7}$ & 0 \\
\hline HU & 0 & 34 & 44 & 0 \\
RU & $\mathbf{2 9}$ & $\mathbf{7 8}$ & 22 & 0 \\
\hline all & 14 & 43 & 29 & 1 \\
\hline
\end{tabular}

How can we analyze and interpret the data? The following observations and conclusions can be drawn:

1. Hypothesis \#1-MPJT informants coming from the same country as the DPT informants will categorize an e-mail as "unclear" not more frequently than those coming from other countries - could be verified for most, but not all e-mails. Noteworthy cases are these:

- DE-2 is unclear to $15 \%$ of the fellow German informants, but to $0 \%$ of the Hungarian and Russian informants.

- FR-1 is unclear to $29 \%$ of the fellow French informants, but for less than $20 \%$ of the informants from the US, Germany, Italy, Finland, Poland, and Russia.

- FR-2 is unclear to 35\% of the fellow French informants, but for less than $20 \%$ of the informants from the US, the UK, Germany, Finland, Poland, and Russia.

The following table indicates which e-mails were considered unclear by more than $25 \%$ of the informants of a group: 
Global Language

\begin{tabular}{|c|c|c|c|c|c|c|c|c|c|c|c|c|}
\hline & DE-1 & DE-2 & DE-3 & DE-4 & FR-1 & FR-2 & FR-3 & FR-4 & IT-1 & IT-2 & US-1 & US-2 \\
\hline UK & & $\mathrm{x}$ & & & $\mathrm{x}$ & & & $\mathrm{x}$ & $\mathrm{x}$ & & & \\
\hline US & & $\mathrm{x}$ & & & & & & $\mathrm{x}$ & $\mathrm{x}$ & $\mathrm{x}$ & & \\
\hline NNS & & & & & & & & $\mathrm{x}$ & $\mathrm{x}$ & & \\
\hline DE & & & & & & & & $\mathrm{x}$ & $\mathrm{x}$ & & \\
\hline FR & & $\mathrm{x}$ & & & $\mathrm{x}$ & $\mathrm{x}$ & & & $\mathrm{x}$ & & & \\
\hline IT & & $\mathrm{x}$ & & & & $\mathrm{x}$ & & & $\mathrm{x}$ & & & \\
\hline FI & $\mathrm{x}$ & & & & & & & $\mathrm{x}$ & $\mathrm{x}$ & & \\
\hline PL & & & & & & & & & & & & \\
\hline HU & & & & & & & & $\mathrm{x}$ & $\mathrm{x}$ & & & \\
\hline RU & & & & & & & & & $\mathrm{x}$ & $\mathrm{x}$ & & $\mathrm{x}$ \\
\hline all & & $\mathrm{x}$ & & & & & & & $\mathrm{x}$ & $\mathrm{x}$ & & \\
\hline
\end{tabular}

The e-mails that most informants had problems with were IT-1, IT-2 and DE-2. DE-2 contains two typos that may cause confusion because they lead to different existing words and may thus cause unclear reference: "... book a double room for 5 days stating the night form 20 to 21 December". The reader may see 5 days on the one hand and 20 to 21 December (which is 2 days or one night) on the other and wonder for which period the guest would like to stay exactly. This confusion may even be enforced by the next brick, which says My dates: Name: Olaf Jansson. The writer probably mixed up data and date. The way it is presented now (with two colons) the reader could think that the date is missing and that the writer continued with his name.The length of the stay is also unclear in IT-2: the missing plural marker in "the night from August 7 to August 9 inclusive" may lead to confusion. The addressee may wonder where the mistake is: should it be nights or August 8? In IT-1 the wrong preposition in "I'm intentioned to spend my holidays in your city by a friend of mine" may lead to confusion, particularly in connection with the request for "a room for us".

2. Hypothesis \#2-MPJT informants coming from the same country as the DPT informants categorize an e-mail as "polite" as much as all countries taken together - is not generally supported by our results. For DE-1, DE-3, FR-2 and IT1 , the number of fellow countrypersons who consider the respective e-mail as polite is quite low in comparison with the number of informants from other countries. In contrast, for FR-4, US-1 and US-2, the number of fellow countrypersons who labeled the respective e-mail "polite" is quite high in comparison with the number of informants from other countries.

3. Hypothesis \#3-non-native MPJT informants will categorize an e-mail more often as "polite" than native informants - could not be verified. The British informants consistently label an e-mail "polite" as often as the non-native group does. In some cases they do this even very clearly (DE-3, FR-2). Similarly, the Americans do not label an e-mail "polite" significantly less frequently than the non-native speaker 
group who shows the lowest percentage value for any of the e-mails selected. In other words: The British adhere to the "let-it-pass" principle more than non-native speakers, and Americans adhere to it not less than non-native speakers.

4. Also of note, though, the average Finn does not categorize a single e-mail as "clear and polite" to a significantly lower percentage than any other average country informant. This means that sometimes the French, sometimes the Italians, sometimes the Germans are most resistent in regarding a message as "polite", but never the Finns. One reason for this may be that according to Hofstede's (2000) study Finland is the only one of these countries that ranks in the lower half of the uncertainty avoidance scale, which means that Finnish culture is characterized rather by tolerance and openness to innovation than by conservatism. However, more studies (and more informants) are required for any definitive judgements.

5. If we take into account the answers of all informants, US-2 was most frequently (63\%) and DE-1 and FR-1 least frequently (30\%) labeled "clear and polite". A ranking of the e-mails most frequently classified as "clear and polite" for the country informant groups looks like this:

\begin{tabular}{|c|c|c|c|c|c|c|c|c|c|c|c|c|}
\hline & DE-1 & DE-2 & DE-3 & DE-4 & FR-1 & FR-2 & FR-3 & FR-4 & IT-1 & IT-2 & US-1 & US-2 \\
\hline UK & & & 2 & 2 & & & & & & & & 1 \\
\hline US & & & & & & 3 & & & & & 2 & 1 \\
\hline NNS & & & 3 & & & 1 & & & & & 2 \\
\hline DE & & & 3 & & & 2 & & & & & 1 \\
\hline FR & & & & & & & 2 & 2 & & & & 1 \\
\hline IT & & & & & & 3 & 3 & 2 & & & & 1 \\
\hline FI & & & & 3 & & 1 & 1 & & & & & \\
\hline PL & $(3)^{*}$ & & & & & & 1 & & & 2 & & \\
\hline HU & 1 & & & & & & & & & 2 & 2 & \\
\hline RU & & 2 & 2 & 2 & & & 1 & & & & & \\
\hline all & & & & 3 & & & 2 & & & & & 1 \\
\hline
\end{tabular}

* = below $\mathbf{5 0 \%}$

The following table indicates which mails were considered "clear, but impolite" by at least $25 \%$ of the informants of a group; if more than half of the country informants considered the mail impolite, this is indicated by "xx": 
Global Language

\begin{tabular}{|c|c|c|c|c|c|c|c|c|c|c|c|c|}
\hline & DE-1 & DE-2 & DE-3 & DE-4 & FR-1 & FR-2 & FR-3 & FR-4 & IT-1 & IT-2 & US-1 & US-2 \\
\hline UK & $\mathrm{xx}$ & & & & $\mathrm{x}$ & & & & & & & \\
\hline US & $\mathrm{x}$ & & $\mathrm{x}$ & $\mathrm{x}$ & $\mathrm{x}$ & & $\mathrm{x}$ & & & & & \\
\hline NNS & $\mathrm{x}$ & $\mathrm{x}$ & $\mathrm{xx}$ & $\mathrm{x}$ & $\mathrm{xx}$ & $\mathrm{x}$ & $\mathrm{x}$ & $\mathrm{x}$ & & & $\mathrm{x}$ & \\
\hline DE & $\mathrm{xx}$ & $\mathrm{x}$ & $\mathrm{xx}$ & $\mathrm{x}$ & $\mathrm{xx}$ & $\mathrm{x}$ & $\mathrm{x}$ & $\mathrm{x}$ & & $\mathrm{x}$ & $\mathrm{x}$ & \\
\hline FR & $\mathrm{xx}$ & $\mathrm{x}$ & $\mathrm{xx}$ & $\mathrm{x}$ & $\mathrm{x}$ & & $\mathrm{x}$ & & & & $\mathrm{x}$ & \\
\hline IT & $\mathrm{x}$ & & $\mathrm{xx}$ & $\mathrm{xx}$ & $\mathrm{xx}$ & & $\mathrm{x}$ & & $\mathrm{x}$ & $\mathrm{x}$ & $\mathrm{xx}$ & \\
\hline FI & $\mathrm{xx}$ & $\mathrm{x}$ & $\mathrm{x}$ & & & & & & & & & \\
\hline PL & $\mathrm{x}$ & $\mathrm{x}$ & $\mathrm{x}$ & $\mathrm{x}$ & $\mathrm{x}$ & $\mathrm{x}$ & $\mathrm{x}$ & $\mathrm{x}$ & $\mathrm{x}$ & & $\mathrm{x}$ & $\mathrm{x}$ \\
\hline HU & & $\mathrm{xx}$ & $\mathrm{xx}$ & $\mathrm{x}$ & $\mathrm{xx}$ & $\mathrm{x}$ & $\mathrm{xx}$ & $\mathrm{x}$ & & & $\mathrm{x}$ & $\mathrm{xx}$ \\
\hline RU & $\mathrm{xx}$ & $\mathrm{x}$ & $\mathrm{x}$ & $\mathrm{x}$ & $\mathrm{xx}$ & $\mathrm{x}$ & & $\mathrm{xx}$ & & $\mathrm{x}$ & $\mathrm{x}$ & $\mathrm{x}$ \\
\hline all & $\mathrm{x}$ & $\mathrm{x}$ & $\mathrm{xx}$ & $\mathrm{x}$ & $\mathrm{xx}$ & & $\mathrm{x}$ & & & & $\mathrm{x}$ & \\
\hline
\end{tabular}

What do the e-mails among the top three polite mails at least in one country have in common? What do the e-mails considered impolite by a large part of the informants have in common? First, it should be emphasized that Hypothesis \#4 could be verified: the salutation form did not play a central role in the readers' judgement. Second, in all e-mails seen as polite the request for a hotel reservation is formulated with I would like or as an interrogatory. This does not mean, though, that I would like is enough for an e-mail to be automatically seen as polite by the average reader. But the e-mails that include $I$ want do rank among those that are predominantly seen as "impolite": DE-3 and FR-1. Apart from these two, DE-1 and DE-4 are also considered "impolite" by a large portion of the informants (excluding the British). DE-1's evaluation may have to do with the formulation "... we will abstain from eating any kind of food at the hotel", which may make the reader think that the sender has already had, or heard of, bad experiences with the hotel food-it may even sound like a threat. DE-4 is a remarkable case because, according to the judgement of all informants taken together, it ranks both among the Top 3 polite e-mails and among the e-mails that more than 25 percent consider impolite. This may be explainable by the fact that, on the one hand, the e-mail includes the expression I would like, but, on the other hand, also the very demanding expression I require; in addition, the sender writes about himself in the third person singular ("... book a double room for Mr. Jan Olafsson") and uses telegraphic style in his second sentence ("Arriving at 26 Dezember, leaving 2 January"). Similarly, FR-3 is among the Top 3, but was regarded as impolite by a considerable number of countries. This may be due to the fact that the writer used the sophisticated expression fortnight, but also kept his letter very brief. Furthermore, it seems that the e-mails that contain telegraphic elements (DE-2, DE-4, US-2) are considered impolite especially by Russians, Poles, and Hungarians. 
6. The two e-mails that received the highest evaluations for the label "overpolite" are DE-1 (19\%) and US-1 (15\%). All others are below 10\%. What those two have in common is the use of sophisticated words (DE-1 abstain, US-1 utilize); however, other e-mails also include elaborate terms without being considered overpolite: FR-2 chambre (probably due to Fr. chambre 'bedroom'), FR-3 fortnight, IT-1 I'm intentioned to... (not even lexicalized, probably due to It. sono intenzionato a...). Whether a larger natural corpus could help us to find out about the effects of waffling is unclear, since there are so many other aspects and slots that may vary.

An additional note: Unfortunately, there were not enough instances to comment on the influence of overdoing explicitness (cf. Seidlhofer 2004), that is the use of unusually explicit constructions (e.g. FR-4 "for a week at this date: 25-27 August" instead of "from 25 to 27 August"), or, more generally, the waffle phenomenon (cf. Blum-Kulka/Olshtain 1986), that is a learner's oversupply of politeness markers, downgraders and longer constructions (DE-1 "I would like to inform you that we will abstain from eating any kind of food" and FR-1 "My first question will concerne the fact that I'm student and I want to know if you...").

In a second study, I have dealt with a face-threatening act. Again, I have first created a DPT for a realistic face-threatening situation in a non-synchronous, written context. As mentioned before, a highly frequented venue of Internet communication is eBay, so the following DPT was created:

At eBay you have a DVD from an X vendor. The internet description classified the quality of the video as "good". However, when you watch the video, the sound contains a lot of hissing noise. Complain to the vendor about this.

In the actual questionnaire, $X$ was replaced by Italian for German informants and by German for informants from other countries. All informants received the text in their mother tongues so that no direction could prompt any standard English words or phrases. Several dozens of texts were produced by informants from a broad range of countries. For the further steps, only countries for which more than 5 texts could be collected were respected: Germany (15), Spain (9), France (7), the US (7). As the communicative success can only be measured through an assessment test, a metapragmatic judgment task had to be created next. The MJT accepted those 3 e-mails per country that turned out to be most typical of each country with regard to

- type of address form (Dear Sir or Madam dominant in DE, ES; no clear preferences in FR and US)

- detailedness of describing the problem (a general statement that the sound is bad is dominant in ES, FR, DE; details on the problems and a general statement are rather evenly distributed in US)

- type of describing the problem ("you/your description said..." vs. "the description said..." is dominant in ES, FR, DE; in the US "the description said..." and "you said" are roughly balanced)

- demand for for further proceeding (refund/new disc) (in FR) or proposal for further proceeding and/or request of proposal for further proceeding or no clear dominance (in US, DE, ES) 
- use of I want/ask you to ... vs. I would like you to ... (dominant in ES) vs. Could you ... vs. no clear dominance (in FR, US, DE)

- inclusion of positive remarks (no in DE, ES, FR; rather no in US)

- inclusion of Thank you (rather yes in FR; rather equal distribution in DE, ES, US)

- inclusion of warnings/threats (legal steps/bad review) (no in DE; rather no in ES, FR, US)

- inclusion of offer to discuss the matter further on the phone (no in US, DE; rather no in ES, FR)

- expressions saying "looking forward to do business again" vs. "never again" (no in DE, FR; rather no in US, ES)

Among the discourse markers that researchers have described as typical for ELF (cf., e.g., House 2010: 376ff.), only so was relevant for this type of script (cf. e-mails DE-3, FR-2, ES$1)$.

The MJT informants - which were not the same as the DPT informants - had to imagine themselves in the position of the vendor:

You frequently sell things on eBay.com to people from all over the world. For a friend you've now sold (under the name vendor123) several copies of a special edition of the Disney film "Bambi" on eBay. The following days you receive these 12 e-mails. Read the emails and say whether you regard them appropriate or not, that is: whether you as a seller feel treated fairly or unfairly.

They then had to decide whether they considered an e-mail by the customer "very fair", "rather fair", "rather unfair", "very unfair" or whether they "can't tell because they don't quite understand the text". Why should fair treatment be linked to communicative success? Trading is successful if customers' needs for fair treatment are fulfilled, i.e. if they get a good DVD or their money as quickly as possible. My assumption is that a customer's complaint, too, will be successful if it is not face-threatening to the vendor. Fair treatment of the vendor will lead to faster service for the customer. In retrospect, the customer will then experience whether the email complaint was communicatively efficient, or successful.

As of yet, the MJT was filled out by

- 68 native speakers, the largest groups being informants from the US (44) and the UK (16),

- 210 non-native speakers, the largest groups being formed by informants from Germany (78), Poland (67), France (15), Finland (11), Italy (11), and Russia (8).

In the tables, the second line gives the percentages of informants who did not quite understand the e-mail. The figures of each first line are the median of answers on the scale "very fair" (3), "rather fair" (2), "rather unfair" (1), "very unfair" (0). The last column shows the Total Politeness Index: the sum of all national medians. 


\section{US-1}

Good morning,

A few days ago I bought a DVD from your company and last night I tried to watch it. You guaranteed that the video would have good quality, but something was wrong with the sound and it made a hissing noise throughout the film. It was difficult to enjoy the movie because I couldn't hear the sound correctly. I would like to mail it back to you in return for another; if that's not possible, I would like to return it in exchange for my money. Please let me know which if these terms you would prefer; thank you for your cooperation. I look forward to doing business with you in the future.

Sincerely,

Leo

\begin{tabular}{|c|c|c|c|c|c|c|c|c|c|c|c|} 
& UK & US & NNS & DE & FR & IT & FI & PL & HU & RU & Tot.PI \\
\hline fairness & 3 & 3 & 3 & 3 & 3 & 3 & 3 & 3 & 3 & 2 & 26 \\
$\begin{array}{c}\text { unintelligible } \\
(\%)\end{array}$ & 0 & 0 & 1 & 0 & 0 & 0 & 0 & 3 & 0 & 0 & \\
\hline
\end{tabular}

\section{US-2}

$\mathrm{Hi}$,

I recently purchased the DVD "Bambi" from your ebay store, and am somewhat dissatisfied with the product. You described the quality of the video as "good", and yet I cannot make out most of the dialogue because of an annoying hissing noise. If possible, I would like to exchange the product for one of better quality, or have my money back.

Kind regards,

David

\begin{tabular}{|c|c|c|c|c|c|c|c|c|c|c|c|}
\hline & UK & US & NNS & DE & FR & IT & FI & PL & HU & RU & Tot.PI \\
\hline fairness & 3 & 3 & 2 & 2 & 2 & 3 & 3 & 2 & 2.5 & 2 & 22.5 \\
$\begin{array}{c}\text { unintelligible } \\
(\%)\end{array}$ & 0 & 0 & 2 & 0 & 0 & 0 & 9 & 6 & 0 & 0 & \\
\hline
\end{tabular}

\section{US-3}

Dear vendor123,

I recently purchased a DVD from you, and although the quality was listed as "good" on the packaging, it was very unsatisfactory during the playback. There was a lot of extraneous noise that greatly interfered with the video quality, and I was wondering if you offer either an exchange policy or a refund policy.

Thank you,

Alba

\begin{tabular}{|c|c|c|c|c|c|c|c|c|c|c|c|}
\hline & UK & US & NNS & DE & FR & IT & FI & PL & HU & RU & Tot.PI \\
fairness & 3 & 3 & 2 & 2 & 3 & 3 & 3 & 2 & 3 & 2 & 24 \\
\hline unintelligible & 0 & 0 & 5 & 4 & 0 & 9 & 0 & 9 & 0 & 0 & \\
\hline
\end{tabular}




\section{DE-1}

Dear Sir or Madam,

Last week I perchased the DVD "bambi" by your ebay-auction. Unfortunately is the quality of the DVD not as good as it was described in your ebay statement. I would consider it best that I receive a quality product for my money or I would like to have my money back. I am willing to send you the DVD to justify my complain.

I am hoping that we will solve this problem by mutual agreement.

Regards,

Gina

\begin{tabular}{|c|c|c|c|c|c|c|c|c|c|c|c|}
\hline & UK & US & NNS & DE & FR & IT & FI & PL & HU & RU & Tot.PI \\
fairness & 2 & 2 & 2 & 2 & 2 & 3 & 2 & 2 & 3 & 3 & 21 \\
$\begin{array}{c}\text { unintelligible } \\
(\%)\end{array}$ & 0 & 0 & 3 & 2 & 7 & 0 & 0 & 6 & 0 & 0 & \\
\hline
\end{tabular}

\section{DE-2}

Dear Sir or Madam,

I am afraid that I need to tell you that the DVD which I bought does not equal the qualities described in the internet. Instead, the sound is very noisy and far away from being good.

Therefore I like to have this DVD exchanged.

If it is possible, please replace it or otherwise please pay the money, that you have already received from me,directly back into my bank account.

Best regards,

Sabrina

\begin{tabular}{|c|c|c|c|c|c|c|c|c|c|c|c|} 
& UK & US & NNS & DE & FR & IT & FI & PL & HU & RU & Tot.PI \\
\hline fairness & 2 & 3 & 3 & 3 & 3 & 3 & 3 & 3 & 3 & 2 & 25 \\
\hline $\begin{array}{c}\text { unintelligible } \\
(\%)\end{array}$ & 7 & 0 & 3 & 4 & 0 & 0 & 0 & 5 & 0 & 14 & \\
\hline
\end{tabular}


DE-3

Hello,

three weeks ago I bought the DVD "Bambi" from your ebay account.

Although the sound quality was described as good, the sound is very noisy and it is hard to understand the dialogues in order to this bad sound quality.

So I ask you to retransfer the money to the my bank account.

Afer the referral I will send the DVD back to your adress.

Thanks for your understanding.

Regards,

Alex

\begin{tabular}{|c|c|c|c|c|c|c|c|c|c|c|c|} 
& UK & US & NNS & DE & FR & IT & FI & PL & HU & RU & Tot.PI \\
\hline fairness & 2 & 2 & 2 & 2 & 2 & 3 & 2 & 2 & 2 & 1 & 18 \\
$\begin{array}{c}\text { unintelligible } \\
(\%)\end{array}$ & 7 & 7 & 5 & 2 & 0 & 9 & 9 & 8 & 0 & 13 & \\
\hline
\end{tabular}

\section{FR-1}

Dear mister,

I write this mail because of $\mathrm{i}$ commanded a DVD on eBay

This DVD was sold by you and is bad, the sound sizzle whereas it had a good mark.

In view of, i will be pay back, or, at least i wish you will substitute this DVD by a new.

Thanks you.

Kindest regards.

\begin{tabular}{|c|c|c|c|c|c|c|c|c|c|c|c|}
\hline & UK & US & NNS & DE & FR & IT & FI & PL & HU & RU & $\begin{array}{c}\text { Tot.P } \\
\text { O }\end{array}$ \\
\hline $\begin{array}{c}\text { fairness } \\
\text { unintelligible } \\
(\%)\end{array}$ & 2 & 2 & 2 & 2 & 2 & 2.5 & 2 & 1 & 1.5 & 1 & 16 \\
\hline
\end{tabular}




\section{FR-2}

Good morning,

I send you that e-mail in order to talk about a DVD, that I bought. In fact, the problem is that the sound crackel and that disappointed me a lot.

Because the E-bay form explain that the DVD was intact.

So, I propose you two solutions, and they are the only solution that I can accept. The first one ; I send you back the DVD, and you send me a new one.

The second one ; you give my money back in cash !

Thanks for your comprehension,

Wait for a response

Bye

Paul

\begin{tabular}{|c|c|c|c|c|c|c|c|c|c|c|c|}
\hline & UK & US & NNS & DE & FR & IT & FI & PL & HU & RU & Tot.PI \\
fairness & 2 & 2 & 2 & 2 & 2 & 2 & 2 & 2 & 2 & 2 & 18 \\
\hline $\begin{array}{c}\text { unintelligible } \\
(\%)\end{array}$ & 7 & 0 & 1 & 0 & 0 & 0 & 0 & 2 & 0 & 0 & \\
\hline
\end{tabular}

\section{FR-3}

Hello. I ordered a DVD two weeks ago through your online-store on Ebay. On the item description, it was written that the quality of the video was good. Unfortunately it is not the case and the sound has a really poor quality. I would like you to replace it or to refund the money I paid. Thanks. Jo

\begin{tabular}{|c|c|c|c|c|c|c|c|c|c|c|c|} 
& UK & US & NNS & DE & FR & IT & FI & PL & HU & RU & Tot.PI \\
\hline fairness & 2 & 1 & 1 & 1 & 1 & 1 & 2 & 1 & 1 & 1 & 11 \\
$\begin{array}{c}\text { unintelligible } \\
(\%)\end{array}$ & 13 & 9 & 2 & 0 & 0 & 0 & 0 & 5 & 0 & 0 & \\
\hline
\end{tabular}

\section{ES-1}

Hello

I just bough you a DVD, and I have heard it in my house recently...and I believe that the sound isn't good. I'm sorry but when I bought it I thought the sound was to be good as it was written so please, i would like to return it back to you. Sorry for the incoveniences. Thank you very much Enrique Garcia

\begin{tabular}{|c|c|c|c|c|c|c|c|c|c|c|c|}
\hline & UK & US & NNS & DE & FR & IT & FI & PL & HU & RU & Tot.PI \\
fairness & 2 & 2 & 2 & 2 & 2 & 2 & 2 & 2 & 2.5 & 2 & 18.5 \\
$\begin{array}{c}\text { unintelligible } \\
(\%)\end{array}$ & 0 & 0 & 4 & 3 & 0 & 0 & 0 & 6 & 0 & 29 & \\
\hline
\end{tabular}




\section{ES-2}

Dear vendor123,

I have watched the DVD you sold me and, contrary to what I was told on ebay, the sound quality is poor and I can't listen to it properly. I'd like to return it to you and that you gave me a refund if possible.

Yours, seller1

\begin{tabular}{|c|c|c|c|c|c|c|c|c|c|c|c|} 
& $\mathrm{UK}$ & $\mathrm{US}$ & $\mathrm{NNS}$ & $\mathrm{DE}$ & $\mathrm{FR}$ & $\mathrm{IT}$ & $\mathrm{FI}$ & $\mathrm{PL}$ & $\mathrm{HU}$ & $\mathrm{RU}$ & Tot.PI \\
fairness & 2.5 & 2 & 2 & 2 & 3 & 2 & 2 & 2 & 2.5 & 1 & 19 \\
$\begin{array}{c}\text { unintelligible } \\
(\%)\end{array}$ & 13 & 9 & 7 & 4 & 0 & 0 & 9 & 11 & 0 & 13 & \\
\hline
\end{tabular}

\section{ES-3}

Dear Mr,

I have received the DVD that I bought you and the sound is not good.

I would like to receive my money back since I believe that the price doesn't match with the quality of DVD.

If you want we can discuss it by phone.

My phone number is 111222333 .

Many thanks

Looking forward to hearing news from you

Nestor

\begin{tabular}{|c|c|c|c|c|c|c|c|c|c|c|c|}
\hline & UK & US & NNS & DE & FR & IT & FI & PL & HU & RU & Tot.PI \\
fairness & 2 & 2 & 2 & 2 & 2 & 1.5 & 2 & 2 & 1.5 & 1.5 & 16.5 \\
\hline $\begin{array}{c}\text { unintelligible } \\
(\%)\end{array}$ & 0 & 0 & 2 & 0 & 0 & 0 & 10 & 5 & 0 & 0 & \\
\hline
\end{tabular}

The ranks according to the Total Politeness Index are these: 
Global Language

\begin{tabular}{|c|c|c|c|}
\hline Rank & E-Mail & Tot.PI & $\begin{array}{c}\text { violations } \\
\text { against StE }\end{array}$ \\
\hline 1 & US-1 & 26 & 0 \\
\hline 2 & DE-2 & 25 & 4 \\
\hline 3 & US-3 & 24 & 0 \\
\hline 4 & US-2 & 22.5 & 0 \\
\hline 5 & DE-1 & 21 & 1 \\
\hline 6 & ES-2 & 19 & 5 \\
\hline 7 & ES-1 & 18.5 & 5 \\
\hline 8 & FR-2 & 18 & 6 \\
\hline 8 & DE-3 & 18 & 5 \\
\hline 10 & ES-3 & 16.5 & 1 \\
\hline 11 & FR-1 & 16 & 10 \\
\hline 12 & FR-3 & 11 & 0 \\
\hline
\end{tabular}

Furthermore, in order to get to know more about informants' motives for the "fair-unfair" rating, I did not use one line for open comments (as did Chen [1996] in her MJTs), but I provided informants with a list of answers and added a line "Other". Here is a simplified illustration of the percentages of informants that ticked a parameter influencing their "fairness" ratings (in contrast to Grzega 2013, the informants that did not tick at least one item in this last part of the questionnaire were not counted although they have completely filled out the rest, i.e. $100 \%$ = informants who did fill out at least something in this part of the questionnaire; if two thirds of all countries pass the 33\%-level, the strategy is in boldprint, if two thirds of all countries pass the 67\%-level, the strategy is in bold-print and underlined): 


\begin{tabular}{|c|c|c|c|}
\hline & $\begin{array}{l}100 \% \geq x \geq \\
67 \%\end{array}$ & $\begin{array}{l}67 \%>x \geq \\
33 \%\end{array}$ & $33 \%>x>0 \%$ \\
\hline $\begin{array}{l}\text { (A) The author used a proper form of address and } \\
\text { greeting. }\end{array}$ & PL & $\begin{array}{l}\text { UK, DE, FR, } \\
\text { IT }\end{array}$ & $\begin{array}{l}\text { US, FI, HU, } \\
\text { RU }\end{array}$ \\
\hline $\begin{array}{l}\text { (B) The author used a proper form of closing } \\
\text { the e-mail. }\end{array}$ & & $\begin{array}{l}\text { UK, FR, IT, } \\
\text { PL, HU, RU }\end{array}$ & US, DE, FI \\
\hline $\begin{array}{l}\text { (C) The author explained in detail what was } \\
\text { the problem with the DVD. }\end{array}$ & $\begin{array}{l}\text { US, UK, } \\
\text { DE, FI, IT, } \\
\text { PL }\end{array}$ & FR, HU, RU & \\
\hline $\begin{array}{l}\text { (D) The author formulated rather a wish than } \\
\text { an order. }\end{array}$ & $\begin{array}{l}\text { UK, DE, } \\
\text { FR, FI, IT, } \\
\text { PL }\end{array}$ & US, HU, RU & \\
\hline (E) The author did not attack me personally. & $\begin{array}{l}\text { US, UK, } \\
\text { DE, FR, FI, } \\
\text { IT }\end{array}$ & PL, HU, RU & \\
\hline $\begin{array}{l}\text { (F) The author mentioned also good aspects of } \\
\text { our deal. }\end{array}$ & & FR, FI, IT & $\begin{array}{l}\text { US, UK, } \\
\text { DE, PL, HU, } \\
\text { RU }\end{array}$ \\
\hline (G) The author said exactly what s/he wants. & UK & $\begin{array}{l}\text { US, DE, FR, } \\
\text { FI, PL, HU, } \\
\text { RU }\end{array}$ & IT \\
\hline $\begin{array}{l}\text { (H) The author named more than one solution } \\
\text { for handling the situation. }\end{array}$ & $\begin{array}{l}\text { US, UK, } \\
\text { DE, FR, FI }\end{array}$ & $\begin{array}{l}\text { IT, PL, HU, } \\
\text { RU }\end{array}$ & \\
\hline $\begin{array}{l}\text { (I) The author gave me a choice for how to } \\
\text { handle the situation. }\end{array}$ & \multirow[t]{2}{*}{$\begin{array}{l}\text { US, DE, FI, } \\
\text { IT, RU }\end{array}$} & \multirow[t]{2}{*}{$\begin{array}{l}\text { UK, FR, PL, } \\
\text { HU }\end{array}$} & \\
\hline (J) The author showed his emotions. & & & $\begin{array}{l}\text { US, UK, } \\
\text { DE, FR, FI, } \\
\text { IT, PL, HU, } \\
\text { RU }\end{array}$ \\
\hline (K) The e-mail was written in good English. & & $\begin{array}{l}\text { US, UK, FI, } \\
\text { IT, PL, RU }\end{array}$ & DE, FR, HU \\
\hline
\end{tabular}

(The answers under the point "Other" were very individual and did not offer any interesting aspects. For classificaitons related to European use vs. non-European use, cf. Grzega 2013: 128f.)

How can we analyze and interpret the data? Based on all these data, we can test the following 7 hypotheses on the "fair-unfair" rating, working with two statistical tests, namely the t-test and the chi-square test (cf. Cochran 1954).

\begin{tabular}{|l|l}
$\# 1$ a. & $\begin{array}{l}\text { MJT informants rate e-mails with the use of Dear }+ \\
\text { sir/madam or the username (vendor 123) higher than } \\
\text { other opening forms (Hello, Good morning, Dear } \\
\text { mister). (This is based on prior ethnographic } \\
\text { observations.) }\end{array}$
\end{tabular}
True, except for US-1 [Hello] and
US-2 [Hi] $)$. However, this result is
not statistically significant
$(\mathrm{t}=1.8818, \mathrm{df}=9, \mathrm{p}=0.0926$ for
group $1 \neq$ group 2 , and $\mathrm{p}=0.9537$ for
group $1>$ group 2$)$. 


\begin{tabular}{|c|c|c|}
\hline $1 \mathrm{~b}$. & $\begin{array}{l}\text { MJT informants rate e-mails with the use of either Hello } \\
\text { or Dear }+ \text { sir/madam or the username (vendor } 123 \text { ) } \\
\text { higher than other opening forms (Hello, Good morning, } \\
\text { Dear mister). (This is based on the first meta-pragmatic } \\
\text { judgement task.) }\end{array}$ & $\begin{array}{l}\text { Not true. But the results are not } \\
\text { statistically significant }(t=-0.1153 \text {, } \\
d f=9, p=0.9108 \text { for group } 1 \text { =group } 2 \text {, } \\
\text { and } p=0.5449 \text { for group } 1>\text { group } 2) \text {. }\end{array}$ \\
\hline & $\begin{array}{l}\text { Mails with violations against Standard English grammar } \\
\text { are not rated lower than mails without violations as long } \\
\text { as they are intelligible (= not more than } 10 \% \text { informants } \\
\text { judging a mail as unintelligible). ("let-pass principle" } \\
\text { observation.) }\end{array}$ & $\begin{array}{l}\text { True, as the differences are } \\
\text { negligible }\left(\mathrm{r}=-0.29 ; \mathrm{r}^{2}=0.09\right) \text {. }\end{array}$ \\
\hline \#3. & $\begin{array}{l}\text { (Obs.: Pragmatic interference is rare:) MJT informants } \\
\text { coming from the same country as the DPT informants } \\
\text { rate an e-mail not higher than those coming from other } \\
\text { countries. }\end{array}$ & $\begin{array}{l}\text { True for FR and DE. Not true for } \\
\text { US-2 }(t=4.081, d f=80, p=0.0001) \\
\text { US-3 }(t=3.8514, d f=92, p=0.0001)\end{array}$ \\
\hline \#4a. & $\begin{array}{l}\text { (Based on the "let-it-pass principle" observed for non- } \\
\text { native speakers:) Non-native MJT informants rank an e- } \\
\text { mail not lower than British informants. }\end{array}$ & $\begin{array}{l}\text { Not true: Not corroborated for } \\
\text { FR-1 }(\mathrm{t}=-1.9583, \mathrm{df}=11, \mathrm{p}=0.0383) \\
\text { US-2 }(\mathrm{t}=-2.5088, \mathrm{df}=18, \mathrm{p}=0.0110) \\
\text { US-3 }(\mathrm{t}=-2.9263, \mathrm{df}=20, \mathrm{p}=0.0042) \\
\text { ES-3 }(\mathrm{t}=-2.0539, \mathrm{df}=18, \mathrm{p}=0.0274) \\
\text { FR-2 }(\mathrm{t}=-2.3272, \mathrm{df}=21, \mathrm{p}=0.0150)\end{array}$ \\
\hline$\# 4 \mathrm{~b}$ & $\begin{array}{l}\text { (Based on the "let-it-pass principle" observed for non- } \\
\text { native speakers:) Non-native MJT informants rate an e- } \\
\text { mail not lower than American informants. }\end{array}$ & $\begin{array}{l}\text { Not true: Not corroborated for } \\
\text { FR-1 }(\mathrm{t}=-2.5395, \mathrm{df}=50, \mathrm{p}=0.0071) \\
\text { US-1 }(\mathrm{t}=-5.0921, \mathrm{df}=128, \mathrm{p}<0.0001) \\
\text { US-2 }(\mathrm{t}=-4.3243, \mathrm{df}=80, \mathrm{p}<0.0001) \\
\text { US-3 }(\mathrm{t}=-3.9728, \mathrm{df}=92, \mathrm{p}=0.0001) \\
\text { ES-1 }(\mathrm{t}=-3.8740, \mathrm{df}=73, \mathrm{p}=0.0001) \\
\text { ES-3 }(\mathrm{t}=-3.4144, \mathrm{df}=80, \mathrm{p}=0.0005) \\
\text { FR-2 }(\mathrm{t}=-2.9422, \mathrm{df}=68, \mathrm{p}=0.0022)\end{array}$ \\
\hline 5. & $\begin{array}{l}\text { The respected non-native speakers attach less value to } \\
\text { the forms of address, greeting and valediction and the } \\
\text { use of standard English grammar than the British and } \\
\text { American informants. (This is based on the "let-it-pass } \\
\text { principle" observed for non-native speakers.) }\end{array}$ & $\begin{array}{l}\text { Not true. (Not corroborated for any } \\
\text { single item by chi-square tests.) }\end{array}$ \\
\hline \#6. & $\begin{array}{l}\text { There are discourse strategies that are more important } \\
\text { for (a) British, (b) American informants than address, } \\
\text { greeting, valediction or the use of standard English } \\
\text { grammar. (This is based on prior ethnographic } \\
\text { observations.) }\end{array}$ & $\begin{array}{l}\text { (According to chi-square tests:) } \\
\text { True for American informants, } \\
\text { namely for E. } \\
\text { Not true for British informants. }\end{array}$ \\
\hline \#7. & $\begin{array}{l}\text { There are discourse strategies that are more important } \\
\text { for the respected non-native speakers than address, } \\
\text { greeting, valediction and the use of standard English } \\
\text { grammar. (This is based on prior ethnographic } \\
\text { observations.) }\end{array}$ & $\begin{array}{l}\text { (According to chi-square tests:) } \\
\text { True, namely for D and C. }\end{array}$ \\
\hline
\end{tabular}

(For hypotheses related to European use vs. non-European use, cf. Grzega 2013: 128f.). 
In sum, many hypotheses that have suggested themselves from prior observations on naturally occurring data could not be verified by the experimental data.

\subsection{The Experienced Layperson as Ethnographer and Some Results}

As criticism against discourse creation and multiple-choice judgement tasks was also raised by others (cf., e.g., Geluykens 2007: 35f.) and as the goal of cross-cultural comparisons is often a more general and abstract one, the technique of a semi-expert interview on communication strategies (SICS) was proposed as an additional technique. The technique (cf. Grzega/Schöner 2008, Grzega 2013: 31f.) is to discover all acceptable utterances as well as their degrees of acceptability and their connotations in specific situations. A SICS can be envisaged as a supplement to traditional ethnographic techniques. The SICS is distributed to persons who deal with language professionally and can therefore be expected to be distinctly sensitive to communicative behavior. They are thus conceived as ethnological semi-experts giving their introspective view of the typical communicative behavior in their speech groups, picturing themselves in the role of someone who explains this to a foreigner. Informants are asked to note down both adequate and inadequate communicative patterns in a given situation. A SICS works with lists of communicative patterns to be chosen from as well as space for adding unprefabricated patterns and further useful information.

\subsection{Semantic Differentials and Some Results}

Production and judgement tests as well as semi-expert interviews work best for scripts with few and brief slots. The more prominent a scenario, the more readily useful the results will be for the EGL learner. However, there are also conversational themes that allow a larger number and variety of slots, in other words: very individual ways of talking, where (prefabricated) patterns do not play an important role. This does not mean that misunderstandings that fall in the realm of pragmalinguistics are excluded. As already said, an area at the edge of semantics and pragmatics is the use of single words with regard to what is beyond the denotational meaning. It would be very unusual if word-connotations were the only language components where non-natives automatically followed native usage. Example 3 in Section 2.1, for instance, suggests that the word fashion triggers different notions in the interviewer's and the interviewee's mind. In Example 2 such connotative differences may rest in the word freedom (or free-time, which the interviewer might have meant). But are the connotatives differences individual or culture-bound? This can only be found out with more informants.

Generally, cross-cultural studies on connotative similarities and differences of words are not very numerous. One reason may be that it is not easy to collect and classify data on cultural differences in a non-cultural way. If informants simply have to give their first associations with certain words, difficulties arise when the answers have to be grouped. Alternatively, Wierzbicka (e.g. 1997) has used a list of semantic primes to describe denotative and connotative aspects of meaning. She has specifically dealt with lexemes for friendship, freedom and fatherland in Australia, Russia, Poland, Germany, and Japan. In the 1950's, Charles E. Osgood and his team created the technique of the semantic differential. With this technique, informants are shown words together with a number of 7-step scales of bipolar antonyms. Informants then have to assign a position on each 7-step scale to a given word. The 
arithmetic means of informant answers express the group connotations of a word. The bipolar antonyms are not necessarily categories that the concept is typically connected with. Osgood and his colleagues rather wanted to detect anthropologically universal principles of structuring the world. From their-also cross-cultural-studies, they concluded that the three universal categories are evaluation (good-bad), potency (strong-weak), and activity (active-passive) (cf. Osgood/Suci 1955, Osgood/Suci/Tannenbaum 1957, Osgood 1964). According to Kumata/Schramm (1956), there are merely two dimensions: the evaluative dimension (good-bad) and the dynamism dimension (strong/active-weak/passive). Gulliksen (1958: 94) suggested to refine semantic differentials by enlarging the 7-step scales to 15-step or even 25-step scales. For the pragmalinguist, though, context-free characterization is particularly interesting when it is more general, not fine-tuned, as then the characteristic feature is also likely to be present in many concrete contexts. In order to find out such basic features, it even seems sufficient to have just 4 steps on scales (strongly $+X$, rather $+X$, rather $-X$, strongly $-X$ ). Instead of adjectival pairs that represent universal dimensions of structuring the world, another approach are words for universal needs, a longterm topic in anthropology. It can then be studied to what degree a word is closely linked with a certain need or the satisfaction of a certain need. A model of universal needs that are presented in scalar way is the one by Martin (1994). Departing from the famous need pyramid by Maslow (1943), Martin thinks that human beings constantly try to discover the best way to control conflicting needs, in particular chaos-order, simplicity - complexity, integrationdifferentiation, freedom — restrictions, emotion — reason, egotism—altruism, individualitycommunity. The latter pair reminds us of one of the basic classificatory principles in crosscultural anthropology (e.g. Hofstede 2000). It is also possible to work with one-dimensional scales, as did Wolf/Polzenhagen (2006). One-dimensional lists of allegedly universal needs that could then be resorted to are offered by Maslow, Max-Neef $(1986,1991)$, and Rosenberg 2003, 2005). Still another approach would be to present a short story, a situation, to informants, connect it to a term and then ask for a reaction, e.g. "In this situation, if you called $\mathrm{X}$ a friend, would you expect rather $\mathrm{A}, \mathrm{B}$ or $\mathrm{C}$ from him?" This is a technique that Trompenaars/Hampden-Turner (1997) have used-however, not in connection with linguafranca issues.

For this study, informants were asked "to connect the words to the elements of the oppositions: this means [...] to say, e.g., whether [they] associate, e.g., the word democracy 'strongly with good', 'rather with good', 'rather with bad', or 'strongly with bad'". They were presented grids of English words (no matter whether native or non-native speaker) that looked like this. 


\begin{tabular}{|c|c|c|c|c|}
\hline & $\begin{array}{l}\text { strongly with } \\
\text { good }\end{array}$ & rather with good & rather with bad & strongly with bad \\
\hline \multicolumn{5}{|l|}{ I associate EUROPE ... } \\
\hline \multicolumn{5}{|l|}{$\begin{array}{l}\text { I associate } \\
\text { DEMOCRACY ... }\end{array}$} \\
\hline \multicolumn{5}{|l|}{ I associate ARTS ... } \\
\hline \multicolumn{5}{|c|}{ I associate FREE-TIME... } \\
\hline \multicolumn{5}{|c|}{ I associate THE PRESS... } \\
\hline \multicolumn{5}{|l|}{ I associate SCHOOL ... } \\
\hline \multicolumn{5}{|c|}{ I associate THE STATE... } \\
\hline \multicolumn{5}{|l|}{ I associate TAXES... } \\
\hline \multicolumn{5}{|l|}{ I associate WEALTH... } \\
\hline I associate WORK... & & & & \\
\hline
\end{tabular}

The set of associations were the classical Osgood scales good/bad, strong/weak, active/passive and the central anthropological scale individuality/community. The selected words are derived from topics that different student groups said to have experienced as probable topics once you went beyond pure small talk with people from other countries.

By February 2013, the semantic differential was completed by

- 109 native speakers, the largest groups formed by informants from the US (72), the UK (19), and Australia (9) and

- 327 non-native speakers, the largest groups being formed by informants from Germany (102), Poland (94), France (23), Finland (18), Hungary (14), Italy (10), Russia (7), and Brazil (7).

If we calculate the median, i.e. the numerical value separating the higher half of the data sample from the lower half (with $1=$ 'strongly with good' .. 4 = 'strongly with bad'), the results are these:

\begin{tabular}{|l|c|c|c|c|c|c|c|c|c|c|c|}
\hline Europe & US & UK & AU & DE & FR & IT & FI & PL & HU & RU & BR \\
\hline good/bad & 1 & 2 & 1 & 1 & 1 & 2 & 1 & 2 & 2 & 1 & 2 \\
\hline strong/weak & 2 & 2 & 1 & 2 & 2 & 3 & 2 & 2 & 2 & 2 & 1 \\
\hline active/passive & 2 & 2 & 2 & 2 & 2 & 2 & 2 & 2 & 2 & 1 & 2 \\
\hline $\begin{array}{l}\text { individuality/ } \\
\text { community }\end{array}$ & 2 & 3 & 2 & 3 & 4 & 3 & 3 & 3 & 2 & 2 & 3 \\
\hline
\end{tabular}

\begin{tabular}{|l|c|c|c|c|c|c|c|c|c|c|c|}
\hline democracy & US & UK & AU & DE & FR & IT & FI & PL & HU & RU & BR \\
\hline good/bad & 2 & 2 & 2 & 1 & 1 & 1 & 1 & 2 & 2 & 2 & 2 \\
\hline strong/weak & 2 & 2 & 2 & 2 & 2 & 2 & 2 & 2 & 3 & 2 & 2 \\
\hline active/passive & 2 & 2 & 2 & 2 & 2 & 2 & 2 & 2 & 2 & 2 & 2 \\
\hline individuality/ & 2 & 3 & 3 & 3 & 3 & 3 & 3 & 3 & 3 & 2 & 3 \\
\hline
\end{tabular}


Global Language

community

\begin{tabular}{|l|c|c|c|c|c|c|c|c|c|c|c|}
\hline arts & US & UK & AU & DE & FR & IT & FI & PL & HU & RU & BR \\
\hline good/bad & 1 & 1 & 1 & 1 & 1 & 1 & 1 & 1 & 1 & 1 & 1 \\
\hline strong/weak & 2 & 2 & 2 & 3 & 2 & 2 & 2 & 2 & 2 & 2 & 2 \\
\hline active/passive & 2 & 2 & 2 & 2 & 2 & 1 & 2 & 2 & 2 & 2 & 1 \\
\hline $\begin{array}{l}\text { individuality/ } \\
\text { community }\end{array}$ & 1 & 2 & 1 & 1 & 2 & 2 & 1 & 2 & 2 & 2 & 1 \\
\hline
\end{tabular}

\begin{tabular}{|l|c|c|c|c|c|c|c|c|c|c|c|}
\hline free-time & $\mathrm{US}$ & $\mathrm{UK}$ & $\mathrm{AU}$ & $\mathrm{DE}$ & $\mathrm{FR}$ & $\mathrm{IT}$ & $\mathrm{FI}$ & $\mathrm{PL}$ & $\mathrm{HU}$ & $\mathrm{RU}$ & $\mathrm{BR}$ \\
\hline good/bad & 1 & 1 & 1 & 1 & 1 & 1 & 1 & 1 & 1 & 1 & 1 \\
\hline strong/weak & 2 & 3 & 2 & 2 & 2 & 2 & 2 & 1 & 2 & 2 & 2 \\
\hline active/passive & 2 & 2 & 2 & 2 & 2 & 1 & 2 & 2 & 2 & 2 & 1 \\
\hline $\begin{array}{l}\text { individuality/ } \\
\text { community }\end{array}$ & 2 & 1 & 2 & 2 & 2 & 2 & 1 & 2 & 2 & 3 & 2 \\
\hline
\end{tabular}

\begin{tabular}{|l|c|c|c|c|c|c|c|c|c|c|c|}
\hline the press & US & UK & AU & DE & FR & IT & FI & PL & HU & RU & BR \\
\hline good/bad & 2 & 3 & 2 & 2 & 2 & 2 & 2 & 2 & 3 & 2 & 3 \\
\hline strong/weak & 2 & 2 & 3 & 2 & 2 & 1 & 2 & 2 & 1 & 2 & 2 \\
\hline active/passive & 2 & 2 & 2 & 2 & 2 & 1 & 2 & 2 & 1 & 2 & 2 \\
\hline $\begin{array}{l}\text { individuality/ } \\
\text { community }\end{array}$ & 3 & 3 & 3 & 3 & 3 & 3 & 3 & 3 & 3 & 2 & 3 \\
\hline
\end{tabular}

\begin{tabular}{|l|c|c|c|c|c|c|c|c|c|c|c|}
\hline school & US & UK & AU & DE & FR & IT & FI & PL & HU & RU & BR \\
\hline good/bad & 1 & 2 & 2 & 2 & 2 & 1 & 1 & 2 & 2 & 1 & 1 \\
\hline strong/weak & 2 & 2 & 2 & 2 & 2 & 3 & 2 & 2 & 2 & 2 & 2 \\
\hline active/passive & 2 & 2 & 2 & 2 & 2 & 3 & 2 & 2 & 2 & 2 & 2 \\
\hline $\begin{array}{l}\text { individuality/ } \\
\text { community }\end{array}$ & 3 & 3 & 4 & 3 & 3 & 3 & 3 & 3 & 4 & 3 & 3 \\
\hline
\end{tabular}

\begin{tabular}{|l|c|c|c|c|c|c|c|c|c|c|c|}
\hline the state & $\mathrm{US}$ & $\mathrm{UK}$ & $\mathrm{AU}$ & $\mathrm{DE}$ & $\mathrm{FR}$ & $\mathrm{IT}$ & $\mathrm{FI}$ & $\mathrm{PL}$ & $\mathrm{HU}$ & $\mathrm{RU}$ & $\mathrm{BR}$ \\
\hline good/bad & 2 & 2 & 2 & 2 & 2 & 2 & 2 & 2 & 2 & 2 & 3 \\
\hline strong/weak & 2 & 2 & 2 & 2 & 2 & 2 & 2 & 2 & 2 & 2 & 3 \\
\hline active/passive & 2 & 1 & 2 & 3 & 2 & 3 & 2 & 2 & 2 & 2 & 3 \\
\hline $\begin{array}{l}\text { individuality/ } \\
\text { community }\end{array}$ & 3 & 3 & 3 & 3 & 3 & 3 & 4 & 3 & 3 & 3 & 4 \\
\hline
\end{tabular}

\begin{tabular}{|l|c|c|c|c|c|c|c|c|c|c|c|}
\hline taxes & $\mathrm{US}$ & $\mathrm{UK}$ & $\mathrm{AU}$ & $\mathrm{DE}$ & $\mathrm{FR}$ & $\mathrm{IT}$ & $\mathrm{FI}$ & $\mathrm{PL}$ & $\mathrm{HU}$ & $\mathrm{RU}$ & $\mathrm{BR}$ \\
\hline good/bad & 2 & 3 & 3 & 3 & 3 & 2 & 2 & 3 & 3 & 3 & 3 \\
\hline strong/weak & 2 & 2 & 2 & 2 & 2 & 1 & 2 & 3 & 2 & 2 & 2 \\
\hline active/passive & 2 & 2 & 3 & 3 & 2 & 3 & 2 & 3 & 2 & 2 & 2 \\
\hline individuality/ & 3 & 3 & 3 & 3 & 3 & 3 & 4 & 3 & 2 & 3 & 3 \\
\hline
\end{tabular}




\begin{tabular}{|c|c|c|c|c|c|c|c|c|c|c|c|}
\hline community & & & & & & & & & & & \\
\hline & & & & & & & & & & & \\
\hline wealth & US & UK & $\mathrm{AU}$ & $\mathrm{DE}$ & FR & IT & FI & PL & $\mathrm{HU}$ & RU & BR \\
\hline $\mathrm{good} / \mathrm{bad}$ & 2 & 2 & 2 & 2 & 2 & 2 & 1 & 2 & 2 & 1 & 2 \\
\hline strong/weak & 2 & 2 & 2 & 2 & 2 & 2 & 2 & 2 & 2 & 2 & 2 \\
\hline active/passive & 2 & 2 & 2 & 3 & 2 & 2 & 2 & 2 & 2 & 2 & 2 \\
\hline $\begin{array}{l}\text { individuality/ } \\
\text { community }\end{array}$ & 1 & 2 & 1 & 2 & 2 & 2 & 2 & 1 & 2 & 2 & 2 \\
\hline
\end{tabular}

\begin{tabular}{|l|c|c|c|c|c|c|c|c|c|c|c|}
\hline work & US & UK & AU & DE & FR & IT & FI & PL & HU & RU & BR \\
\hline good/bad & 2 & 2 & 2 & 2 & 2 & 1 & 1 & 2 & 2 & 1 & 1 \\
\hline strong/weak & 2 & 2 & 2 & 2 & 2 & 1 & 2 & 2 & 2 & 2 & 2 \\
\hline active/passive & 1 & 2 & 2 & 1 & 2 & 1 & 2 & 2 & 2 & 1 & 1 \\
\hline $\begin{array}{l}\text { individuality/ } \\
\text { community }\end{array}$ & 2 & 2 & 3 & 2 & 3 & 2 & 2 & 2 & 2 & 1 & 2 \\
\hline
\end{tabular}

It is obvious that even among the national groups of native speakers the associations are not always unanimous. Europe, for example, is rather associated with 'community' by the British informants, but rather with 'individuality' by the US and Australian informants. Democracy is associated with 'rather individuality' by the Americans, but with 'rather community' by British informants. Taxes and the press are associated with 'rather good' by US informants, but with 'rather bad' by British informants. Most other nations link taxes to the label 'rather bad', save the Italian and the Finnish informant group - the latter mirroring other findings on Scandinavian associations with taxes (cf. Grzega 2012: 40, Grzega 2013: 102). Where the native-speaker groups share associations on one side ( $1 / 2$ or $3 / 4$ respectively), the following deviating associations among non-native speakers are interesting: democracy evokes individuality in the US and Russia, while in the other countries the community concept is in the fore; Europe is labeled 'rather weak' by Italians, arts 'rather weak' by Germans, free-time 'rather community' by Russians, school 'rather weak' and 'rather passive' by Italians, the state 'rather bad' by Brazilians, 'rather weak' by Brazilians and 'rather passive' by Brazilians, Germans and Italians, taxes 'rather community' by Hungarians and 'rather weak' by Poles, wealth 'rather weak' by Germans, and work 'rather community' by Australians and the French. Brief, English words do not necessarily trigger native speakers' associations in non-native speakers. And this happens in speakers' minds and may well go unnoticed. Studies on connotations will be especially important with words that denote concepts that are apparently universal.

\subsection{The Informant Quantity Problem}

Despite the comparatively high number of informants that could be gathered for the above studies, the number is still low in relation to the vast amount of non-native speakers - and we should add: non-native speakers from many different cultures. In the studies presented, despite the partly rather low number, a certain representativity is given for Europe's geocultural zones (on these, cf. Grzega 2013: 4). As it will probably be unrealistic to include informant groups from all or most nations, it is such representative selections of nations from 
different geocultural areas that we are likely to have to concentrate on. Another option would be to group informants from single nations into geo-cultural groups. As a basis for such categorizations anthropological works such as the ones by Hofstede (2000) and Trompenaars/Hampden-Turner (1997) may be used. For this, it would be useful to have a net of representative ELF informants that would fill out questionnaires.

\section{Teaching English as a Global Language (TEGL)}

As English is not simply the language of a specific culture, but a global means of communication, we should ask if and how this should lead to separate comprehensive concepts for teaching English as a global language. Yet the general awareness of the special role and several linguists' claims to reflect this role of English in language teaching have so far hardly had any influence curriculum planning all over Europe and beyond (Seidlhofer 2007: 46, Grzega 2012c). Even courses termed International Business English mostly, at least in many parts of Europe, teach learners the American way of doing business.

As of yet, aside from some ideas for global textbooks (cf., e.g, Kubanek [1999] for Britain) and university TESOL programs (cf., e.g., Dürmüller [2008] for Switzerland), suggestions for the implementation of Jenkins' Lingua Franca Core (Walker 2011), the only comprehensive and coherent instructional concept for English as a lingua franca, addressing both adults and children, is Basic Global English (BGE, http://www.basicglobalenglish.com). Any concept for TEGL should include ELF research results. And this is what BGE does. BGE does away with the native-speaker model in all aspects and does not aim at making learners adopt British or American speech, behavior or thinking; rather, learners should be able to keep their identities, but be able to talk about themselves and ask about others in an atmosphere of tolerance and empathy, with respect to basic situations in intercultural exchanges around the world. In a sense, BGE means learning intercultural communicative competence in English, it means learning how to be a global citizen.

\subsection{General Principles for TEGL}

Many textbooks used at school give details on addressing and greeting. The preliminary results of the studies above suggest that their treatment is actually not so strict in the texttypes analyzed. But the text-types analyzed, despite their prominence, do not even occur in all textbooks - similar things can be observed for textbooks for adult courses. The only type of formal letters that occurs in all textbooks taken into account is the job application. However, for this genre, learners should be advised to get their letter proofread by someone with advanced skills anyway. Consequently, instructors may want to consider including other prominent text-types, such as complaints. For these, the preliminary results suggest that instructors should not focus too much on spelling and grammar beyond basic grammar. What they should focus on are fixed structural bricks, connotations and communicative strategies, i.e. the socio-pragmatic side of language, especially where learners' own conversational strategies seem to differ clearly from those of other cultures. Prior linguistic studies may lead to even more concrete guidelines. From the above studies, we could, for instance, deduce the following Do's and Dont's: 
- "When you write an e-mail to make a room reservation to a US or European hotel, use would constructions. Do not use telegraphic style."

- "When you write an e-mail of complaint about a broken product to a US or European vendor, do not attack the vendor personally, but do explain in detail what the problem was and say explicitly what you want in order to solve the problem, but formulate it as a wish rather than an order. It may be good to name more than one solution and to give the vendor a choice for how to handle the situation. It may be helpful to use a common form of polite valediction, such as Sincerely." (With more studies, more general formulations may suggest themselves.)

- "Know that the word taxes may trigger less negative associations among Scandinavians than among other Europeans." (With more informants, more global formulations may suggest themselves.)

- "Know that free-time makes Russians think of community, while citizens of the US, the EU and Brazil think of individuality." (With more informants, more global formulations may suggest themselves.)

The following aspects could serve as principles, or guidelines, for TEGL, no matter at which level. This means that the principles can already be used at a beginner's level, which would in part fully reverse the sequence suggested by classical curricula.

- Linguistic input comes from both native speakers and diverse non-native speakers.

- Cultural information does not automatically cover the US and the UK, but big global lines or the countries the learner group is interested in.

- Error evaluation is more refined. Deviations from standard grammar in oral situations are penalized according to their disturbance of global intelligibility and according to native and non-native speakers' judgements as appropriate with respect to the situation. This will result in a larger range of acceptable forms, at least in oral contexts. The same holds true for deviations from standard pronunciation. The fear that learners may not acquire a native-near pronunciation once they have grown accustomed to a non-native accent runs counter the many positive experiences with learners who are given appropriate acoustic and cognitive input at quite an advanced level.

- There should be a focus on the pragmatic/illocutionary/connotative force of words and structures.

- Learners are not taught what will work with native speakers, but what will work with people from all or most cultures or what will work with people from the cultures that the learner group is interested in (including the active raise of cultural awareness when in an intercultural situation as well as strategies for getting out of communicative breakdowns that seem to have pragmalinguistic triggers).

- Learners are made aware of the doubtful use of figurative expressions when conversing with other non-native speakers, especially at lower levels. The risk of communicative discomfort is relatively high. 
- The learners have a share in saying to what degree they want to acquire native-speaker competence, once the level of intelligibility is reached.

While for the linguist and the advanced intercultural learner differences between cultures are may be more interesting than commonalities, the "intercultural beginner" needs linguistic patterns that work transculturally, globally. TEGL concepts should respect this. The next section will illustrate how the concept Basic Global English teaches such transcultural strategies for the elementary level of itnercultural learning.

\subsection{The Concept of Basic Global English (BGE)}

My original motivation to develop BGE, as a linguist and as someone who has been teaching languages to many different age-groups, was to see in what way I can contribute to the solution of societal problems. After all, (global) communicative skills are attached a central role in economic and political observations (e.g. Grzega 2005a). BGE incorporates linguafranca research and second-language acquisition research. BGE, whose development was cofunded by the EU, is an offer to beginners who want to learn English as a tool for global communication. It is now a central offer at the Europäisches Haus Pappenheim, EHP (http://www.ehp-online.eu). In addition, the EHP enables solid academic research to enlarge the set of learning bricks or to incorporate new ELF findings. I have already extensively described the linguistic and also the didactic ingredients of BGE on other occasions (e.g. Grzega 2005b, 2008, 2011 and Grzega/Schöner 2007, with further bibliographical hints, http://www.basicglobalenglish.com), so that I keep the description to a minimum degree here.

\subsubsection{The Linguistic Components of BGE}

BGE covers the first levels of language learning (roughly up to level B1 of the Common European Framework of Reference for Languages [CEFR], without the notion of standardness). As communicative breakdowns are more often connected to lexis and communicative strategies than to grammatical and phonetic issues, the focus in BGE is on words (including connotations) and communicative strategies. Learners acquire 750 general and 250 individual words. They also learn about prominent cultural differences in the connotations of words, e.g. the symbolic value of lucky and unlucky numbers, the use of brother, the associations with work and free-time [these only in adult classes]). They also see that they can enlarge their word-stock with word-formation techniques, that they should avoid highly idiomatic expressions or mark them as such, that the world is categorized in different ways in different cultures. Furthermore, they acquire interculturally successful communicative strategies (e.g. presenting oneself, overcoming obvious and alleged communicative breakdowns, buying things, small-talk, negotiating meaning). The "intercultural newcomer" needs strategies that can be labeled "likely to be transculturally successful, as indicated by quantitative research". These strategies are, in contrast to guidelines for intercultural communication in general, not simply expressed in general terms, but accompanied with concrete linguistic forms, e.g.

- Use "could you / would you + infinitive" as strategies that are felt neither too direct nor too indirect. 
- Use the sentence This is how we say in our country as a pre-empting or as a conflictsolving strategy to indicate that the sentence may not be interpretable in a literal way.

- Use Hello as a neutral greeting forms in face-to-face meetings and e-mails.

The offer of concrete forms has shown to be important for beginners. Dialogues that deal with complaints about purchased products with faults include the sentence How can we solve the problem?, so that learners see that it is a good global way to first give the one who caused the problem the chance to solve it. All these strategies are also in line with the studies carried out above. Furthermore, the re-formulation of sentences that the interlocutor has obviously not understood or presumably not understood is also taught and trained with concrete examples. Strategies that, according to research, seem to develop in ELF talk in a natural way do not have to be taught explicitly to beginners. The BGE strategies also serve to consolidate an attitude of tolerance and empathy in learners. As to grammar, BGE unites forms that have empirically been proven successful in lingua-franca communication. BGE does not ban native variants, though; learners must not be impeded to acquire a more native-like form of English if they personally wish to. Similar principles hold true for pronunciation rules. As already said, BGE must be considered constant work in progress that is to respect new relevant findings in ELF research.

\subsubsection{The Didactic Components of BGE}

The didactic components are based on research on L2 acquisition, psychological-neurological research and my experience as an observer and as a teacher. The relevant literature has already largely been quoted elsewhere (cf., e.g, Grzega/Stenzenberger 2011 and Grzega 2012). Among the more recent reference studies are Spitzer 2002, Teuchert-Noodt et al. 2003, Pienemann 2005, Edmonson/House 2006, Butzkamm/Caldwell 2009 as well as Grzega/Klüsener 2012). The most important elements are these:

- Discoursive skills are practiced from Lesson $1 \mathrm{on}$. This implies both linguistic and social skills. For this, the didactic model LdL (for German Lernen durch Lehren 'Learning by Teaching') has turned out to be highly fruitful. Its central element is to confide as many teaching responsibilities to the learner as possible and to inspire as many learners as possible to commit themselves in the highest possible degree of activity. Often, the technique of teacher-role rotation can be used: the teacher only starts asking a learner L1, but then this role of asking is delegated to L1, and afterwards from L1 to L2 (who has now answered L1) etc.

- The input consists of authentic material from natives and near-natives, but also from (successful) non-natives as well as examples and analyses of communicative breakdowns.

- The evaluation of forms is not based on the question "correct or incorrect standard English?", but on the question "communicatively successful or unsuccessful?". This also includes what we know about pragmatic patterns. For example, the use of intonation questions is accepted, but supplemented by the comment that with Yes-No questions the standard word-order allows an easier pragmalinguistic interpretation on the hearer's side. This sort of evaluation holds true in the normal lesson progression as 
well as in test situations (e.g. dialogic tasks where the teacher plays an interlocutor from a different country and reacts, based on his knowledge of ELF research and typical interlanguage features of someone from the other country).

- BGE teachers accept the heterogeneity of learners with respect to talent for language learning, interests and biographies. Learner autonomy is thus promoted in the selection of countries and 250 words, which can ideally be supplemented by pragmalinguistic hints.

\subsubsection{Empirical Results}

What can we say about the communicative skills of the learners at the end of a BGE course. The effectiveness and efficiency was quantitatively tested in two children groups and one adult group. The two children groups participated in a non-compulsory BGE course with weekly 45-minute lessons over one school year. This covered only half of the planned BGE lessons, but the mass of children interested forced us to hold two BGE classes with one weekly lesson instead of one BGE class with two weekly lessons. The children's skills were tested after one year (quantitative approach: oral test and written test). As a result of the study (cf. Grzega 2011a, Grzega 2012c), the average BGE child can be said to command a larger word-stock than a child after one year of 2 classical lessons per week. Furthermore, compared to learners after three years of English with 2 lessons of English in the first two years and 7 lessons in the third year, the average child from the BGE class can, with respect to pragmalinguistic aspects,

- $\quad$ speak more freely

- communicate, interrogate and carry out dialogs more easily

- show more social awareness, as they are seen as more tolerant and more empathetic

Some people's fear that BGE children would typically be very far away from native English is not justified. The effective pronunciation was laudably noted by an expert group from a German teacher association (cf. Judenmann 2009).

The adult group spent 15 lessons of BGE. The study of the adults' skills consisted of a written test (listening comprehension, reading comprehension, intercultural competence and writing skills), two oral tests in the form of role plays (one for emergency situations where the learners had to phone someone at the imagined hotel, with the researcher playing the receptionist) and a self-evaluation questionnaire (in the form of a Likert scale). The results (cf. Grzega 2011a, Grzega/Stenzenberger 2011) allow BGE to be seen as an effective and efficient offer to reach the communicative skills of level B1 of the Common European Framework of Reference for Languages (CEFR).

Three more outcomes illustrate the effectiveness of BGE. At the end of the course, one of the adult participants was able to present his technological company at a one-week international fair. The BGE lessons are structured in a way that even a 91-year-old man was able to acquire communicative competence for his central situations as a tourist and honorary municipal archivist. Furthermore, BGE allowed the children to get along so well during the visit at their Italian partner school that they came back asking for an Italian course in addition to BGE. 
This does not mean that there were no critical moments for the learners. But they had the skill to realize and overcome them.

\section{$4 \quad$ Final Remarks}

The article has combined a number of studies, predominantly on pragmalinguistic aspects, but also on phonological, morphological, and syntactic aspects. I have investigated both natural and elicited language data from synchronous oral and non-synchronous written contexts, using both qualitative approaches and quantitative approaches (one type of DPTs, two types of MJTs and one type of semantic differential). The studies have shown that quantitative analyses with experimental methods often falsify hypotheses that have suggested themselves from normative language guides and from prior qualitative research (without claiming, of course, that the results offered there were wrong).

- The let-it-pass principle seems followed by natives as much as by (European) nonnatives, sometimes even more than some non-natives (e.g. Poles and Russians); such other non-native cultures should definitely be more integrated in the English classroom.

- The central elements that decide over the success of the text-types analyzed lie definitely more in the slots ("middle-slot relevance") between the greeting phrase and the valediction (at least in the US and Europe) .

- Since these middle slots look different from culture to culture, it is these slotsincluding address terms to some degree - for which we need to develop a feeling, for which we need Do's and Don'ts for different target cultures or for transcultural communication in general.

The article has shown that native speakers' use is not always what learner-books claim ("learner-book illusion"), but that non-native speakers seem to stick to that use ("learner-book nimbus") and that they sometimes use quite complex structures, apparently in order to raise politeness, although this would not be necessary for native speakers ("complex-is-polite principle").

The article has shown that native speakers' use is not always what learner-books claim ("learner-book illusion"), but that non-native speakers seem to stick to that use ("learner-book nimbus") and that they sometimes use quite complex structures, apparently in order to raise politeness, although this would not be necessary for native speakers ("complex-is-polite principle").

Finally, the article has shown how the fruits of analyzing ELF are turned into a benefit for EGL teachers. It has shown that dialogic skills for intercultural communication in English can effectively be taught at the elementary level through the concept Basic Global English (BGE), which strives for including results from existing pragmalinguistic and other studies on ELF, particularly transculturally effective strategies. The study has also stressed that a concept for teaching EGL needs to be regarded as constant work-in-progress so that it can easily integrate further insights into ELF. 
Analyzing and teaching English as a lingua franca is a multifacetous topic. There are numerous constellations of situations where people from different cultures exchange utterances for a certain goal by resorting to English abound. Despite the many valuable studies that we already have - there are still a lot of key scenarios and key-words waiting for analysis. I have not been questioning the value of any study here, but I would like to stress that we will need to work with both naturally occurring and elicited data with a variety of analyzing methods (simply to overcome the limits that each method must have). However, I also have the impression that - due to the many variables that we have in situations-datacollecting methods of experimental design will be more important. It would also be useful to have a world-wide net of ELF informants grouped into representatives of geo-cultural zones, and it would be helpful to have a databank for the results of such studies. Such a databank can then be an immediate benefit for TEGL, which would require that TEGL concepts have stable principles and are nonetheless adaptable enough, once new observations have been made. Making our knowledge on a global communication tool rapidly accessible to the global community_-we should not abstain from doing so.

\section{References}

Austin, John (1962): How to Do Things with Words. Oxford: Oxford Univery Press.

Bateson, George (1972): Steps to an Ecology of Mind. San Francisco: Chandler.

Beebe, Leslie M. (1985): "Speech Act Performance. A Function of the Data Collection Procedure?". Paper presented at the 6th Annual TESOL and Sociolinguistics Colloquium at the International TESOL Convention, New York (quoted in Wolfson/Marmor/Jones 1989).

Björkman, Beyza (2008): "'So where we are?' Spoken Lingua Franca English at a Technical University in Sweden". English Today 24/2: 35-41.

Blom, Jan-Petter/Gumperz, John J. (1972): "Social Meaning in Linguistic Structure. CodeSwitching in Norway". In: Gumperz, John J./Hymes, Dell (eds.) (1972): Directions in Sociolinguistics. The Ethnography of Communication. New York, Holt, Rinehard and Winston: 407-434.

Blum-Kulka, Shoshana/Olshtain, Elite (1986): "Too Many Words: Length of Utterance and Pragmatic Failure". Journal of Pragmatics 8: 47-61.

Blum-Kulka, Shoshana/House, Juliane/Kasper, Gabriele (eds.) (1989): Cross-Cultural Pragmatics. Requests and Apologies. Norwood, N.J.: Ablex.

Brouwer, Dédé/Gerritsen, Marinel/deHaan, Dorian (1979): "Speech Differences Between Women and Men. On the Wrong Track?". Language in Society 8/1: 33-50.

Brown, Penelope/Levinson, Stephen (1987): Politeness: Some Universals in Language Usage. Cambridge: Cambridge University Press.

Butzkamm, Wolfgang/Caldwell, John W. (2009): The Bilingual Reform. A Paradigm Shift in Foreign Language Teaching. Tübingen: Narr.

Candlin, Christopher N. (1976): "Communicative Language Teaching and the Debt to Pragmatics". In: Rameh, Cléa (ed.) (1976): $27^{\text {th }}$ Round Table Meeting. Washington, D.C.: 237-256.

Chen, Hongyin Julie (1996): Cross-Cultural Comparison of English and Chinese Metapragmatics in Refusal. Ph.D. thesis. Indiana. 
CIDE = Procter, Paul (ed.) (2008): Cambridge International Dictionary of English. Cambridge: Cambridge University Press.

Cochran, William G. (1954): "Some Methods for Strengthening the Common $\chi^{2}$ Tests". Biometrics 10: 417-451.

Cogo, Alessia/Dewey, Martin (2012): Analysing English as a Lingua Franca. A CorpusDriven Investigation. London: Continuum.

DCE = Longman Dictionary of Contemporary English $\left({ }^{4} 2005\right)$, Essex: Pearson Education.

Deci, Edward L./Ryan, Richard M. (1985): Intrinsic Motivation and Self-Determination in Human Behavior. New York: Plenum.

Dolilina, Inga B. (2002): "Evidence for the Imperative as a Speech-Act Category." LACUS Forum (LACUSF) 28: 197-208.

Dürmüller, Urs (2008): "Towards a New English as a Foreign Language Curriculum for Continental Europe". In: Locher, Miriam A./Strässler, Jürg (eds.) (2008): Standard and Norms in the English Language. Berlin/New York, Mouton de Gruyter: 393-414.

Edmondson, Willis J./House, Juliane ( $\left.{ }^{3} 2006\right)$ : Einführung in die Sprachlehrforschung. Tübingen: Francke.

Firth, Alan (1996): "The Discursive Accomplishment of Normality. On 'Lingua Franca' English and Conversation Analysis". Journal of Pragmatics 26: 237-259.

Geluykens, Ronald (2007): "On Methodology in Cross-Cultural Pragmatics". In: Kraft, Bettina/Geluykens, Ronald (eds.) (2007): Cross-Cultural Pragmatics and Interlanguage English. München, LINCOM: 21-72.

Goffman, Erving (1955): "On Face-Work: An Analysis of Ritual Elements in Social Interaction". Psychiatry 18: 213-231.

Goffman, Erving (1967): Interaction Ritual. Essays on Face-to-Face Behavior. New York: Doubleday Anchor.

Grice, Herbert Paul (1975): "Logic and Conversation". In: Cole, Peter/Morgan, Jerry L. (eds.) (1975): Syntax and Semantics. Vol. 3: Speech Acts. New York, Academic Press: 41-58.

Grzega, Joachim (1997): "Österreichisch, Bairisch, Bayrisch, Deutschländisch Beobachtungen zu Lexik und Idiomatik". In: Muhr, Rudolf/Schrodt, Richard (eds.) (1997): Österreichisches Deutsch und andere nationale Varietäten plurizentrischer Sprachen in Europa. Wien, Hölder-Pichler-Tempsky: 147-171.

Grzega, Joachim (2005a): "Socioeconomic Linguistics (or Linguistic Socioeconomics) - a New Field of European and Global Research and Teaching". Journal for EuroLinguistiX 2: $19-43$.

Grzega, Joachim (2005b): "Towards Global English via Basic Global English (BGE). Socioeconomic and Pedagogic Ideas for a European and Global Language". Journal for EuroLinguistiX 2 (2005): 65-164.

Grzega, Joachim (2006): EuroLinguistischer Parcours. Kernwissen zur europäischen Sprachkultur. Frankfurt am Main: IKO.

Grzega, Joachim (2008): "Lingua Franca English as a Way to Intercultural and Transcultural Competence. Basic Global English (BGE) and Other Concepts of English as a Lingua Franca". Journal for EuroLinguistiX 5: 134-161.

Grzega, Joachim (2011): "Putting English for Global Communication into Teaching Practice. The Concept of Basic Global English (BGE) at Primary School". In: Busch-Lauer, 
Ines/Fiedler, Sabine (eds.) (2011): Sprachraum Europa - Alles Englisch oder ...? Berlin, Frank und Timme: 107-141.

Grzega, Joachim (2012a): Europas Sprachen und Kulturen im Wandel der Zeit. Eine Erlebnisreise. Tübingen: Stauffenburg.

Grzega, Joachim (2012b): "Second-Language Varieties. Global English". In: Bergs, Alexander/Brinton, Laurel (eds.) (2012): English Historical Linguistics. An International Handbook. Berlin etc., de Gruyter: 2135-2150.

Grzega, Joachim (2012c): "Basic Global English (BGE) as a Quick Way to Global Communicative Competence. Empirical Results from Primary School". In: Böttger, Heiner/Schlüter, Norbert (eds.) (2012): Fortschritte im Frühen Fremsprachenlernen: Ausgewählte Tagungsbeiträge Eichstätt 2011. München, Domino: 131-141.

Grzega, Joachim (2012d): "Developing Europragmatics-Food for a Eurolinguistic Stepchild". Journal for EuroLinguistiX 9: 11-50.

Grzega, Joachim (2013): Studies in Europragmatics. Theoretical Foundations and Practical Implications. Wiesbaden: Harrassowitz.

Grzega, Joachim/Klüsener, Bea (2012): LdL für Pepe, Pfeiffer und die Pauker. Unterrichtstipps nach 30 Jahren bewährtem, verlässlichem, kreativem und effektivem Lernen durch Lehren. Berlin: epubli.

Grzega, Joachim/Schöner, Marion (2007): "Basic Global English (BGE) as a Way for Children to Acquire Global Communicative Competence. Report on an Elementary School Project". Journal for EuroLinguistiX 4: 5-15.

Grzega, Joachim/Schöner, Marion (2008): "ELiX's Contribution to the Year of Intercultural Dialogue". Journal for EuroLinguistiX 5: 1-12.

Grzega, Joachim/Stenzenberger, Sandra (2011): "Teaching Adults Intercultural Communication Skills with Basic Global English (BGE)". Journal for EuroLinguistiX 8: 34-131.

Gulliksen, Harold (1958): "How to Make Meaning More Meaningful". In: Snider/Osgood (1969): 89-95. Reprinted from: Contemporary Psychology 3. 115-118.

Hall, Edward T. (1959): The Silent Language. Garden City: Doubleday.

Hall, Edward T. (1963): The Hidden Dimension. Garden City: Doubleday.

Hall, Edward T. (1976): Beyond Culture. Garden City: Doubleday.

Hinkel, Eli (1997): "Appropriateness of Advice. DCT and Multiple Choice Data". Applied Linguistics 18/1: 1-26.

Hofstede, Geert (2000): Culture's Consequences. Thousand Oaks: Sage.

House, Juliane (1999): "Misunderstanding in Intercultural Communication. Interaction in English as a Lingua Franca and the Myth of Mutual Intelligibility". In: Gnutzmann, Claus (ed.) (1999): Teaching and Learning English as a Global Language. Tübingen, Stauffenburg: 73-89.

House, Juliane (2009): "Introduction. The Pragmatics of English as a Lingua Franca". Intercultural Pragmatics 6/2: 141-145.

House, Juliane (2010): "The Pragmatics of English as a Lingua Franca". In: Trosborg, Anna (ed.) (2010): Pragmatics across Languages and Cultures. Berlin/New York, Mouton de Gruyter: 363-387.

Hymes, Dell H. (1964): "Toward Ethnographies of Communication. The Analysis of Communicative Events". American Anthropologist 66/6/2: 1-34. 
Hymes, Dell H. (1972a): "The Ethnography of Speaking". In: Fishman, Joshua (ed.) (1972): Readings in the Sociology of Language. The Hague, Mouton: 99-138.

Hymes, Dell H. (1972b): "On Communicative Competence". In: Pride, John/Holmes, Janet (ed.) (1972): Sociolinguistics. Harmondsworth, Penguin: 269-293.

Jakobson, Roman (1960): "Linguistics and Poetics". In: Sebeok, Thomas (ed.) (1960): Style in Language. New York etc., Wiley: 350-373.

James, Allan (2000): "English as a European Lingua Franca. Current Realities and Existing Dichotomies". In: Cenoz, Jasone/Jessner, Ulrike (eds.) (2000): English in Europe: The Acquisition of a Third Language. Clevedon, Multilingual Matters: 22-37.

James, Carl (1998): Errors in Language Learning and Use. Exploring Error Analysis. London: Longman.

Jenkins, Jennifer (2003): World Englishes. A Resource Book for Students. London: Routledge. Jenkins, Jennifer/Cogo, Alessia/Dewey, Martin (2011): "Review of Developments in Research into English as a Lingua Franca". Language Teaching 44/3: 281-315.

Judenmann, Wolfgang (2009): "Gespräch zum Grundschulenglisch an der Katholischen Universität Eichstätt: Expertengruppe erörtert Schnittstellenproblematik". Das Gymnasium in Bayern 8-9/2009: 63.

Kasper, Gabriele/Dahl, Merete (1991): "Research Methods in Interlanguage Pragmatics". Studies in Second Language Acquisition 13: 215-247.

Kirkpatrick, Andy (2010): English as a Lingua Franca in ASEAN. A Multilingual Model. Hong Kong: Hong Kong University Press.

Kubanek, Angelika (1999): "Frühes Fremdsprachenlernen in Europa". In: HermannBrennecke, Gisela (ed.) (1999): Frühes schulisches Fremdsprachenlernen zwischen Theorie und Empirie. Münster, LIT: 156-176.

Kumata, Hideya/Schramm, Wilbur (1956): "A Pilot Study of Cross-Cultural Meaning". In: Snider/Osgood 1969: 273-282. Reprinted from: Public Opinion Quarterly 20: 229-238.

Labov, William (1966): The Social Stratification of English in New York City. Diss. Washington.

Lavid, Julia (2000): "Cross-Cultural Variation in Multilingual Instructions. A Study of Speech Act Realisation Patterns". In: Ventola, Eija (ed.) (2000): Discourse and Community. Doing Functional Linguistics. Tübingen, Narr: 71-85.

Leech, Geoffrey (1983): Principles of Pragmatics. London: Longman.

Lim, Tae-Seop (2003): "Language and Verbal Communication Across Cultures". In: Gudykunst, William B. (ed.) (2003): Cross-Cultural and Intercultural Communication. Thousand Oaks, Sage: 53-72.

Martin, Jean-Pol (1994): Vorschlag eines anthropologisch begründeten Curriculums für den Fremdsprachenunterricht. Tübingen: Narr.

Maslow, Abraham (1943): "A Theory of Human Motivation". Psychological Review 50: 370396.

Max-Neef, Manfred (1986): Desarrollo a escala humana. Una opción para el futuro. Santiago de Chile: CEPAUR.

Max-Neef, Manfred (1991): Human Scale Development. Conception, Application and Further Reflections. New York: Apex.

Meierkord, Christiane (1996): Englisch als Medium der interkulturellen Kommunikation. Untersuchungen zum non-native-/non-native-speaker-Diskurs. Frankfurt am Main: Lang. 
Mole, John (1998): Mind Your Manners. London/Naperville: Brealey.

Mollin, Sandra (2006): Euro-English. Assessing Variety Status. Tübingen: Narr.

Morris, Desmond (1977): Manwatching. A Field Guide to Human Behavior. London: Stein and Day.

Morrison, Terri/Conaway, Wayne A. (22006): Kiss, Bow, or Shake Hands. How to Do Business in Sixty Countries. Avon: Adams Media.

Mortensen, Janus (2013): "Notes on English Used as a Lingua Franca as an Object of Study". Journal of English as a Lingua Franca 2/1: 25-46.

OALD = Turnbull, Joanna ( $\left.{ }^{8} 2010\right)$ : Oxford Advanced Learner's Dictionary. Berlin: Cornelsen.

Olshtain, Elite/Blum-Kulka, Shoshana (1984): "Cross-Linguistic Speech Act Studies. Theoretical and Empirical Issues". In: MacMathuna, Liam/Singleton, David/Svartvik, Jan (eds.) (1984): Language Across Culture. Dublin, Irish Association for Applied Linguistics: 235-248.

Osgood, Charles E. (1964): "Semantic Differential technique in the Comparative Study of Cultures". In: Snider/Osgood (1969): 303-334. Reprinted from: American Anthropologist 66. 171-200.

Osgood, Charles E./Suci, George J. (1955): "Factor Analysis of Meaning". In: Snider/Osgood (1969): 42-55. Reprinted from Journal of Experimental Psychology 50. 325-338.

Osgood, Charles E./Suci, George J./Tannenbaum, Percy H. (1957): The Measurement of Meaning. Urbana: University of Illinois Press.

Pienemann, Manfred (2005): Cross-Linguistic Aspects of Processability Theory. Amterdam/Philadelphia: John Benjamins.

Prodromou, Luke (2008): English as a Lingua Franca. A Corpus-based Analysis. London: Continuum.

Rosenberg, Marshall (2003): Nonviolent Communication. A Language of Life. Encinitas: Puddledancer Press.

Rosenberg, Marshall (2005): Speak Peace in a World of Conflict. What You Say Next Will Change Your World. Encinitas: Puddledancer Press.

Searle, John R. (1969): Speech Acts: An Essay in the Philosophy of Language. Cambridge: Cambridge University Press.

Searle, John R. (1976): "A Classification of Illocutionary Speech Acts". Language in Society 5: 1-23.

Seidlhofer, Barbara (2004): "Research Perspectives on Teaching English as a Lingua Franca". Annual Review of Applied Linguistics 24: 209-239.

Seidlhofer, Barbara (2007): "Common Property. English as a Lingua Franca in Europe". In: Cummins, Jim/Davison, Chris (eds.) (2007): International Handbook of English Language Teaching. New York, Springer: 137-153.

Snider, James G./Osgood, Charles E. (eds.) (1969): Semantic Differential Technique. A Sourcebook. Chicago/New York: AVC.

Spitzer, Manfred (2002): Lernen. Gehirnforschung und die Schule des Lebens. Heidelberg/Berlin: Spektrum.

Swan, Michael/Smith, Bernard (eds.) (2001): Learner English. A Teacher's Guide to Interference and Other Problems. Cambridge: Cambridge University Press. 
Teuchert-Noodt, Gertraud et al. (2003): Lernen durch Lehren. Physiologische Grundlagen des Lernens. Göttingen: IWF.

Thomas, Jenny (1983): "Cross-Cultural Pragmatic Failure". Applied Linguistics 4: 91-112.

Trompenaars, Fons/Hampden-Turner, Charles (1997): Riding the Waves of Culture. Understanding Cultural Diversity in Business. London: Nicholas Brearley.

Walker, Robin (2011): Teaching the Pronunciation of English as a Lingua Franca. Oxford: Oxford University Press.

Weiss, Edmond H. (2005): The Elements of International English Style. A Guide to Writing Correspondence, Reports, Technical Documents, Internet Pages for a Global Audience, Armonk, NY: M.E. Sharpe.

Wierzbicka, Anna (1997): Understanding Cultures Through Their Key Words. English, Russian, Polish, German, and Japanese. New York/Oxford: Oxford University Press.

Wolf, Hans-Georg/Polzenhagen, Frank (2006): "Intercultural Communication in English. Arguments for a Cognitive Approach to Intercultural Pragmatics". Intercultural Pragmatics 3: 285-321. 